\title{
Freshwater-adapted sea bass Dicentrarchus labrax feeding frequency impact in a lettuce Lactuca sativa aquaponics system
}

\author{
Paraskevi Stathopoulou ${ }^{1}$, Panagiotis Berillis ${ }^{\text {Corresp., } 1}{ }^{1}$, Nikolaos Vlahos ${ }^{1,2}$, Eleni Nikouli ${ }^{1}$, Konstantinos A. Kormas ${ }^{1}$, \\ Efi Levizou $^{3}$, Nikolaos Katsoulas ${ }^{3}$, Elena Mente ${ }^{1}$ \\ ${ }^{1}$ Department of Ichthyology and Aquatic Environment, School of Agricultural Sciences, University of Thessaly, Volos, Greece \\ 2 Department of Animal Production, Fisheries and Aquaculture, School of Agricultural Sciences, University of Patras, Mesolonghi, Greece \\ 3 Department of Agriculture Crop Production and Rural Environment, School of Agricultural Sciences, University of Thessaly, Volos, Greece \\ Corresponding Author: Panagiotis Berillis \\ Email address: pveril@uth.gr
}

The aim of this study is to investigate the effect of 3 daily fish feeding frequencies, 2, 4 and 8 times per day (FF2, FF4, and FF8, respectively) on growth performance of sea bass (Dicentrarchus labrax)and lettuce plants (Lactuca sativa) reared in aquaponics. 171 juvenile sea bass with an average body weight of $6.80 \pm 0.095 \mathrm{~g}$ were used, together with 24 lettuce plants with an average initial height of $11.78 \pm 0.074 \mathrm{~cm}$ over a 45 -day trial period. FF2 fish group showed a significantly lower final weight, weight gain and specific growth rate than the FF4 and FF8 groups. Voluntary feed intake was similar for all the three feeding frequencies treatmens $(p>0.05)$. No plant mortality was observed during the 45-day study period. All three aquaponic systems resulted in a similar leaf fresh weight and fresh and dry aerial biomass. The results of the present study showed that the FF4 or FF8 feeding frequency contributes to the more efficient utilization of nutrients for better growth of sea bass adapted to fresh water while successfully supporting plant growth to a marketable biomass. 
1 Impact of freshwater-adapted sea bass (Dicentrarchus labrax) 2 feeding frequency in a lettuce (Lactuca sativa) aquaponics system

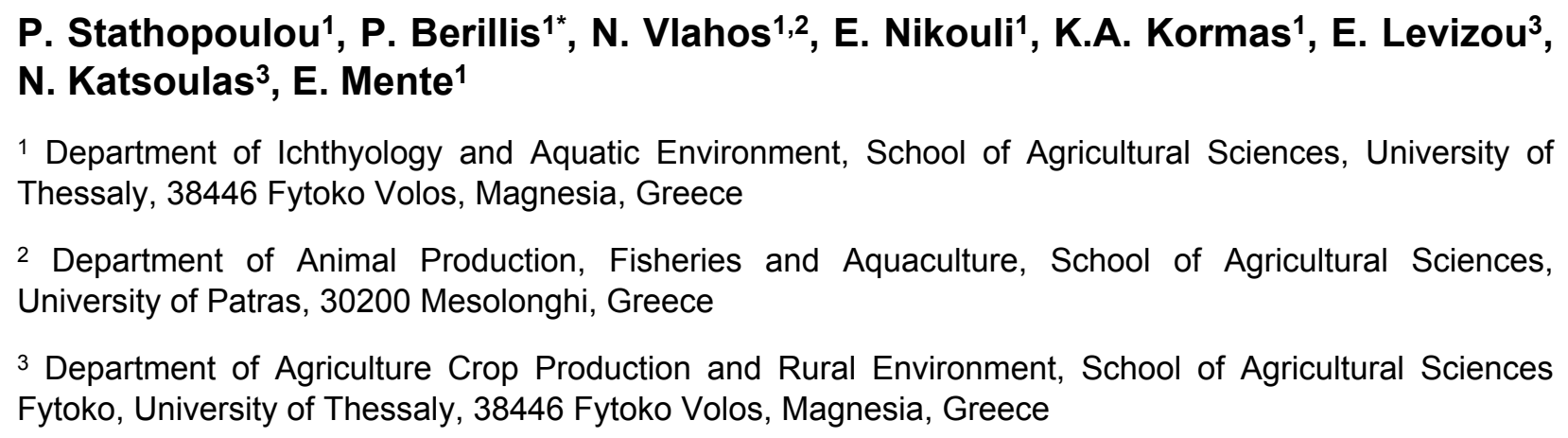

\section{Abstract}

Aquaponic culture is an innovative, sustainable and environmentally friendly method for both fish and plant production. In this study the effect of three different feeding frequencies (2, 4 and 8 times per day) was tested on the growth performance of combined cultivation of sea bass and lettuce plants in a fresh water aquaponics system. Juvenile sea bass with average body weight of $6.80 \pm 0.095 \mathrm{~g}$, together with lettuce plants with average initial height of $11.78 \pm 0.074 \mathrm{~cm}$ were used over a 45-day trial period. Increased feeding frequency (4 and 8 times per day) resulted in higher grow performance parameters for fish, while the voluntary feed intake and the lettuce growth performance were similar for all the three feeding frequencies treatments. No plant mortality was observed during the 45-day study period. The results of the present study indicate that increasing fish feeding frequency results to a more efficient utilization of nutrients for better growth of sea bass adapted to fresh water while successfully supporting plant growth to a marketable biomass.

Keywords: aquaponics; feeding frequency; juvenile sea bass; lettuce; water reuse;

\section{Introduction}

The world's population growth, climate change, soil degradation, water pollution and food security management are some of the problems related to food production for human consumption. Aquaponic culture is an innovative and sustainable method for both fish and plant production and is environmentally friendly in relation to aquaculture fish and soil monocultures [1]. The flexibility of an aquaponic system allows it to grow a 
large variety of vegetables, herbs, ornamental and aquatic plants to cater to a broad spectrum of consumers. Aquaponic products are organic and pesticide free, with a small environmental footprint [2]. Aquaponic growth contributes to water resource management, biodiversity conservation and energy savings [3]. In aquaponics, soil is not needed, and only a small amount of water is required as the systems do not typically discharge or exchange water under normal operation but instead recirculate and reuse water very effectively. Thus, aquaponic systems can be set up in areas that have traditionally poor soil quality or contaminated water [2].

Freshwater fish, especially tilapia species, carp, perch and catfish, are the main cultured species $[4,5,6]$, along with some crustacean species such as Cherax quadricarinatus [7] and Procambarus spp. [8]. Recent research by Knaus \& Palm [9] suggests multispecies cultivation is more efficient in an aquaponic system.

The ammonia oxidation to nitrite and nitrate via Nitrosomonas sp. and Nitrobacter sp. bacteria, is the basic principle of aquaponics. Ammonia released by fish through their metabolism is oxidized by nitration into nitrate ions [10]. Nitrate is useful for the plants and harmless (not toxic) for fish. Finally, the water is transferred back to the fish tanks and is nitrate-free [11]. Fish, plants and bacteria must coexist in balance in an aquaponic system. Therefore, the system type, the size of the filter, fish species, fish biomass and plant species and biomass should be carefully chosen. Proper combination of fish and plants leads to successful production without downgrading water quality [11]. The total biomass of fish should be calculated in comparison with plant biomass and the oxidizing capacity of the filter [12]. If fish and plant biomasses are in appropriate proportions, the fish-produced daily ammonia is sufficient to meet $80 \%$ of the daily plant nutrition needs [13]. Lower plant biomass will lead to nutrient accumulation in the systems, as a higher plant biomass will lead to slower plant growth [14].

Fish feed supplies most of the essential nutrients required for optimal plant growth with the exception of $\mathrm{Ca}, \mathrm{K}$ and $\mathrm{Fe}$, which are usually inadequate and must be supplemented in aquaponic systems [15]. Nitrogen and phosphorus in an aquaponic system are derived from fish food. Therefore, the rate of ammonia production depends on food quantity, its protein composition and the feeding frequency [16]. The 5\% (approximately) of feed is remained unconsumed by fish, and the rest $95 \%$ is ingested and digested. From the total amounts of nitrogen and phosphorus contained in the consumed food, only $30-40 \%$ is used by fish for their metabolism and growth [17]. The remaining $60-70 \%$ is released in the form of faeces, urine and ammonia [17]. The protein content of the fish diet differs between fish species and ages. A high protein content leads to better diet convertibility and improves fish growth [18]. Approximately 1 $\mathrm{kg}$ of fish feed containing $30 \%$ crude protein releases approximately $27.6 \mathrm{~g}$ of $\mathrm{N}$, and 1 $\mathrm{kg}$ of fish biomass releases $90.4 \mathrm{~g}$ of $\mathrm{N}$ and $10.5 \mathrm{~g}$ of $\mathrm{P}$ [17]. Many carnivorous fish species are less able to utilise dietary carbohydrates and cellulose contained in plant cells [19]. A plant-based protein fish diet can lead to higher plant biomass compared to 
an animal-based protein fish diet, but the growth rate of the carnivorous fish will be lower [20].

Nutritional status and feeding rhythm are factors that can affect the fish daily patterns of deamination of proteins and nitrogenous wastes. The feeding frequency and the feeding time affect ammonia production and the catabolism of proteins [21]. According to Gelineau et al. [22], ammonia production and protein catabolism are lower in fish fed at dawn than in those fed at midnight. Among the different feed management practices proven to maximize the benefit of feeding, feeding frequency plays an important role in regulating the feed intake, minimize feed wastage and fish growth [23-25]. The optimal feeding frequency is very important to ensure optimum fish growth, survival, improved immunity and stress resistance [23]. Feed loss and faecal waste is the largest contributor to solid waste in fish culture. The amount and relative composition of faecal material will be determined by the indigestible nutrients of the diet. An increased feeding frequency can lead to increased fish growth rates and increased amounts of excretion but lower food digestibility and water quality degradation [24, 25]. Plants also show daily rhythms in nitrogen uptake. According to Steingrover et al. [26], the nitrate concentration in the leaves increases during the night, as the uptake rate of nitrate by the roots increases at that time. Therefore, an increased feeding frequency contributes to more efficient plant nutrition [27].

Since the late 1980s, sea bass has become increasingly important in Europe, particularly for the Mediterranean region, with a steady increase in demand [28]. Sea bass (Dicentrarchus labrax) has not been used frequently in aquaponics. It is a euryhaline species, ideal for aquaponics with low salinity water in combination with edible or aromatic plants. Several studies have shown that sea bass can survive and grow in brackish water [29] and successfully be adapted to freshwater [30]. Increased mortality in freshwater adaptation can sometimes be detected, as fish in freshwater allocate more energy for osmoregulation than those in seawater. The success of sea bass to enter estuaries and river mouths may depend on a high degree on tissue resistance to changes in the plasma ion-osmotic status [31-33]. The habitat of fish plays an important role in their welfare and growth. The adaptation of a euryhaline fish from sea water to fresh water can affect its food digestibility [34]. The frequency of feeding can affect the fish's nitrogen and energy utilization. In sea bass, a feeding frequency of 1-3 meals per day promotes better growth performance and food consumption rates (FCR) [35], but this can vary with the time of year, fish size, fish feed and the production system.

The aim of this study was to evaluate the effect of 3 daily feeding frequencies $(2,4$ and 8 meals daily) on water quality, growth performance and histology of sea bass (Dicentrarchus labrax) adapted to freshwater in an aquaponic system. In addition, it examines which is the most efficient feeding frequency for sea bass in an aquaponic 
121 system that ensures the combined maximum growth performance of sea bass and 122 lettuce plants (Lactuca sativa).

\section{Material and Methods}

\subsection{Aquaponic system and experimental set-up}

Three (3) autonomous aquaponic systems with a total volume of $500 \mathrm{~L}$ each were constructed. Each system consisted of 3 glass fish tanks $(50 \mathrm{~cm} \times 50 \mathrm{~cm} \times 50 \mathrm{~cm})$ with a $100 \mathrm{~L}$ water volume each and a $26 \mathrm{~L}$ hydroponic cultivation tank $(112 \mathrm{~cm} \times 73 \mathrm{~cm}$ x $20 \mathrm{~cm}$ ) paved with clay pebble $(8-16 \mathrm{~mm}$ ) substrate (fig 1, fig 2). Each aquaponic system's nitrification process was enchased by a biological sump filter $(100 \mathrm{~cm} \times 50 \mathrm{~cm}$ $x 48 \mathrm{~cm}$ ) with a total volume of $184 \mathrm{~L}$. Salinity was gradually decreased 4 units per week until it was stabilized to $<1 \mathrm{ppt}$.

Sump filter construction was previously reported by Vlahos et al [36]. The sump filter was divided into three sections (fig 1). Suitable media, providing a specific surface area (SSA) for nitrifying bacteria colonization, covered the most of the filter area. The mechanical filter covered an area of $1250 \mathrm{~cm}^{2}$ and consisted of three layers of fibreglass material, creating in this way a $30 \mathrm{~cm}$ thick layer to retain the solid residues from the fish tanks (uneaten food and faeces). The biological filter covered an area of $2150 \mathrm{~cm}^{2}$ and was fixed by a mixed media of $20 \mathrm{~L}$ of porous cylindrical substrate $\mathrm{K} 1$ (10 $\mathrm{mm}$ diameter each), a $10 \mathrm{~L}$ ceramic ring (15 mm diameter each) and $10 \mathrm{~L}$ bioballs (30 $\mathrm{mm}$ diameter each). A pump (Aqua Medic OR $2500 \mathrm{~L} / \mathrm{h}, 38 \mathrm{~W}, 2.6 \mathrm{~m} \mathrm{~h}_{\text {max }}$ ) was placed in the last part of the filter to supply the aquaponic system with water through the filter $(\mathrm{Q}=6.27 \mathrm{~L} / \mathrm{min})$. Clay pebble substrate of the hydroponic tank also provided sufficient biofiltration, increasing the efficiency of the system. In each system, a high-pressure sodium $400 \mathrm{~W}$ lamp (Sylvania) was placed at a distance of $65 \mathrm{~cm}$ from the surface of the hydroponic tanks, ensuring this way the appropriate light for the plants. A winder photoperiod of $10 \mathrm{~h}$ light, $14 \mathrm{~h}$ dark was set up. An air-lift pump was used to recycle the water through a filter bed during the experiments (adjusted flow $1.53 \mathrm{~L} / \mathrm{min}$ ), thus creating a filtration speed (V) of $1.79 \mathrm{~cm} / \mathrm{min}$ [36]. The oxygen saturation levels were between $75 \%$ and $80 \%$. Water flow from the hydroponic tank to the fish tank and to the sump filter was performed by gravity (fig 1). The setup period of the systems lasted 2 months to develop the biological filter. According to Hirayama [37], 40-60 days are necessary for the establishment of bacteria and the satisfactory oxidation of ammonia to nitrate ions.

At the beginning of the experiment, an initial period of $24 \mathrm{~h}$ was used to permit any trace of chlorine to escape. Ten grains of a previously conditioned freshwater aquarium's filter bed were introduced to each aquaponic system, serving as inocula for nitrification bacteria. A total of $0.2 \mathrm{~g}$ of $\mathrm{NH}_{4} \mathrm{Cl}$ as an ammonia source was added and dissolved in each system. Water temperature $\left({ }^{\circ} \mathrm{C}\right)$ and $\mathrm{pH}$ of fish tanks were recorded daily, while oxygen concentration $(\mathrm{mg} / \mathrm{L})$, electrical conductivity $(\mathrm{mS} / \mathrm{cm})$ and salinity were recorded every three days. Temperature, $\mathrm{pH}$ and the oxygen concentration were 
165

166

167

168

169

170

171

172

173

174

175

176

177

178

179

180

181

182

183

184

185

186

187

188

189

190

191

192

193

194

195

196

197

198

199

200

201

202

203

204

205

206

207

208

209

210

measured with multimeter sensors (Hach, HQ40d); electrical conductivity was measured using a multimeter (Crison, CM35); and salinity was measured using an optical refractometer (ATC).

\subsection{Experimental design, fish rearing and plant growth conditions}

Two hundred (200) juvenile seabass individuals of 1-2 $\mathrm{g}$ were transported from a local commercial fish hatchery, (SELONTA SA) located at Tapies-Pelasgia, at the Department of Ichthyology and Aquatic Environment (University of Thessaly), in special transport bags with oxygenation. Upon the arrival of the juvenile fish at the laboratory, they were placed for 3 hours in aquariums filled with water of the same salinity $(25 \%$ ) as the transport water. Thereafter, salinity was gradually reduced by removing seawater and simultaneously adding fresh water to the desired salinity of $20 \%$. Every 7 days, the salinity was gradually reduced by 4 ppt. During adaptation, fish were fed to satiation twice a day. The temperature, $\mathrm{pH}$ and electrical conductivity (EC) were recorded daily. Total ammonia $(\mathrm{mg} / \mathrm{L})$, nitrites $(\mathrm{mg} / \mathrm{L})$ and nitrates $(\mathrm{mg} / \mathrm{L})$ in the water column were measured weekly (API AMMONIA $\mathrm{NH}_{3} / \mathrm{NH}_{4}{ }^{+}$TEST KIT, API NITRATE $\mathrm{NO}_{3}{ }^{-}$TEST KIT and API NITRITE $\mathrm{NO}_{2}{ }^{-}$TEST KIT were used respectively). Adaptation of fish to salinity $<1 \mathrm{ppt}$ lasted 60 days [38]. Upon successful adaptation of the fish to fresh water, 19 fish were placed in each fish tank of the aquaponic systems and left for 15 days before the beginning of the experiment to permit their acclimation. Fish number was chosen according to Hirayama (1974) [37] equation taking into account the equilibrium between the purification of the water and the pollution of the water as a result of the feeding and excretion of the fish. At the end of acclimation, their weight and total length were measured. Fish were placed in the aquaponic fish tanks in such a way that there were no statistically significant differences in initial weights and lengths among aquaponic fish tanks.

At the end of the acclimation period a total of 171 individuals juvenile sea bass, Dicentrarchus labrax, with an average body weight of $6.80 \pm 0.10 \mathrm{~g}$ and an average body length of $8.62 \pm 0.05 \mathrm{~cm}$, were placed in the aquaponic fish tanks ( 9 fish tanks in total, 19 individual/tank). All experimental procedures were conducted according to the guidelines of the EU Directive 2010/63/EU regarding the protection of animals used for scientific purposes and were applied by FELASA accredited scientists (functions A-D). The experimental protocol was approved by the Ethics Committee of the Region of Thessaly, Veterinary Directorate, Department of animal protection-Medicines-Veterinary applications (n. 18402/05-09-2019). Experiment was conducted at the registered experimental facility (EL-43BIO/exp-01) of the Laboratory of Aquaculture, Department of Ichthyology and Aquatic Environment, University of Thessaly.

Fish were fed daily at $5 \%$ of their body weight with a commercial floating pellet diet $(55 \%$ protein and $15 \%$ crude fat). Feed was distributed throughout the day (24 hours) at three different feeding frequencies (FF) of 2, 4 and 8 meals/day over 45 days. The time period of 45 days was chosen for the best growth of the lettuce plants [6]. Each aquaponic system was represented by all three feeding frequencies (fig. 1). Feeding was performed in a semi-automatic way. Feeding until 18:00 h (1 meal for FF2,

Peer) reviewing PDF | (2021:02:58306:1:2:NEW 15 Apr 2021) 
2112 meals for FF4 and 4 meals for FF8) was performed by hand, and the other meals 212 were performed with automatic feeders. The feeding rate was adjusted to fish weight 213 every 15 days. Fish tanks were cleaned every day by siphoning, and uneaten food was removed. Daily food consumption per fish tank is calculated by the difference between the amount fed and the amount of uneaten feed collected (corrected for leaching losses) [36]. At the end of the experiment, fish were anaesthetized with Tricaine methanesulfonate (MS 222), and their final fish body weights and lengths were measured.

Lettuce plants (L. sativa var. Musena) were grown in an unheated greenhouse until the 6-true-leaf stage. Five days prior to their transfer to the aquaponic system, $\mathrm{Fe}$ (Fe-DTPA), Ca (foliar application) and $\mathrm{K}(\mathrm{KOH})$ fertilization was performed. A total of 24 lettuce seedlings were chosen, showing no statistically significant differences in their morphometric characteristics (height, number of leaves). Eight lettuce plants were evenly placed in each hydroponic bed, $20 \mathrm{~cm}$ apart. Plant number and density was chosen according to the dimensions of the hydroponic tank and the plant positions were carefully selected to ensure the homogeneity of the light environment; thus, each plant was exposed to $400-500 \mu \mathrm{mol} \mathrm{m} \mathrm{m}^{-2} \mathrm{sec}^{-1}$ of photosynthetically active radiation (PAR). As the aquaponics systems were indoor systems, artificial light was used for the plants. The artificial light was supplied by a 400 W HPS lamp placed $65 \mathrm{~cm}$ above each growing area and accompanied by a timer for accurate control of the photoperiod (10 h light: $14 \mathrm{~h}$ dark). Plant height as well as the number of leaves were monitored every 15 days. No extra $\mathrm{Ca}, \mathrm{K}$ or $\mathrm{Fe}$ was added to the aquaponic system.

234

235

236

237

238

239

240

241

242

243

244

245

246

247

248

249

\subsection{Water quality indicators}

Ammonium $\left(\mathrm{NH}_{4}{ }^{+}\right)$, ammonia $\left(\mathrm{NH}_{3}\right)$, nitrate and phosphate ions were monitored once a week before the daily first fish feeding. Water samples were taken at the water inlet point (GBin) and at the exit point (GBout) of the hydroponic cultivation tank. All measurements were performed using a Hach DR3900 model photometer with special pre-weighted reagents.

The filter's hydraulic loading ratio $(H L R)$, recycled ratio $(r)$, the hydraulic retention time of the water in the filter bed (HRT), the specific surface area of the filter (SSA) nad the volume of filter media $\left(\mathrm{V}_{\text {media }}\right)$ were calculated according to the equations described by Endut et al. [12] and Huguenin \& Colt [39].

$\operatorname{HLR}(\mathrm{m} /$ day $)=$ flow rate $(\mathrm{Q}) /$ total surface area of the trough

$\mathrm{HRT}(\min )=($ surface area water $\mathrm{x}$ depth $\mathrm{x}$ porosity of gravel trough/flow rate)

SSA $\left(\mathrm{m}^{2} / \mathrm{m}^{3}\right)=$ Surface area of filter media/volume of the filter media

Vmedia $\left(\mathrm{m}^{3}\right)=$ surface area of the filter media/SSA

$r=$ volume of recycled water/volume of the system 
250 Production rate of ammonia nitrogen (PTAN) was calculated according to the below 251 equation described by Dediu et al. [40].

252 PTAN $(\mathrm{mg} / \mathrm{g}$ fish $/ \mathrm{h})=\left(\mathrm{C}_{\mathrm{e}}-\mathrm{C}_{\mathrm{i}}\right){ }^{*} \mathrm{Q} / \mathrm{W}$,

253 where: $C_{e}, C_{i}$ inlet and outlet ammonia concentration (mg/L), W: mean fish body weight 254 in the tank $(\mathrm{g}), \mathrm{Q}$ : flow rate(L/h).

255

256

257

258

259

260

261

262

263

264

265

266

267

268

269

270

271

272

273

274

275

276

2.4. Fish and plants growth performance indicators

At the end of the 45-days, fish growth performance was calculated as below,

- Specific Growth Rate, SGR (\%/day) $=\left[\left(\ln W_{\text {fin }}-\ln W_{i}\right) / \Delta t\right] \times 100$

- Weight Gain, WG (gr) $=\mathrm{W}_{\text {fin }}-\mathrm{W}_{\mathrm{i}}$

- Voluntary Feed Intake, VFI $\left(\% \mathrm{~W}_{\text {day }}{ }^{-1}\right)=100 x$ food consumed $(\mathrm{g}) /\left[\left(\mathrm{W}_{\text {in }}+\mathrm{W}_{\text {fin }}\right) / 2 x \Delta \mathrm{t}\right]$

- $\quad$ Feed Conversion Ratio $(\mathrm{FCR})=$ Feed consumed/WG where $W_{\text {in }}$ and $W_{\text {fin }}$ are the initial and final weight of the fish respectively, and $\Delta t$ is the duration of the experiment in days.

Plant growth performance was calculated:

- Stem height $(\mathrm{cm})$

- Number of leaves

- Leaf fresh weight $(\mathrm{gr})=$ Total fresh weight of leaves/ Number of leaves

- Total fresh aerial biomass $(\mathrm{gr})=$ Total fresh weight of leaves + Stem fresh weight

- Total dry aerial biomass $(\mathrm{gr})=$ Total dry weight of leaves + Stem dry weight

- Total produced biomass $\left(\mathrm{kg} / \mathrm{m}^{2}\right)=$ Total fresh weight of aerial part/cultivated area

- Root dry biomass (gr)

\subsection{Fish histology and gut microbiota structure}

Euthanasia of animals followed the EU Directive 2010/63/EU and FELASA guidelines and performed through an overdose of Tricaine methanesulfonate (MS 222, $300+\mathrm{mg} / \mathrm{L})$. At the end of the experiment, five fish per tank were removed for histopathological examination, as previously described by Vlahos et al. [36]. Fish were placed immediately on ice after euthanization. Samples of liver, midgut, kidney and gill were dissected from each fish. Tissue samples were fixed in Davidson' fixative for $24 \mathrm{~h}$ at $4^{\circ} \mathrm{C}$ followed by dehydration in graded series of ethanol, immersion in xylol and embedding in paraffin wax. Thin sections of 4-7 $\mu \mathrm{m}$ were mounted, deparaffinized, rehydrated, stained with Hematoxylin-Eosin, mounted with Cristal/Mount and examined for alterations with a microscope (Axiostar plus Carl Zeiss Light Microscopy, Carl Zeiss Ltd, Gottingen, Germany) under a total magnification of 100X and 400X. A semi - 
288

289

290

291

292

293

294

295

296

297

298

299

300

301

302

303

304

305

306

307

308

309

310

311

312

313

314

315

316

317

318

319

320

321

322

324

quantitative grading system was used in order to quantify the histopathological alterations of the examined tissues [36]. Severity grading used the following system: Grade 0 (not remarkable), Grade 1 (minimal), Grade 2 (mild), Grade 3 (moderate), Grade 4 (severe).

For midgut microbiota analysis, three fish at day 0 and three fish per feeding frequency treatment at days 0,15 and 45 were sacrificed.. Midgut samples were removed after dissection and DNA was extracted with DNA Mini kit (QIAGEN, Germany). Bacterial diversity was assessed by amplification of the V3-V4 region of the bacterial 16S rDNA gene on the MiSeq Illumina platform 2x300 bp (MRDNA Ltd., Shallowater, city, TX, USA, sequencing facilities) using the primer pair S-D-Bact-0341b-S-17 (5'-CCTACGGGNGGCWGCAG-3') and S-D-Bact-0785-a-A-21 (5'GACTACHVGGGTATCTAATCC-3') [41, 42]. Polymerase Chain Reaction (PCR) was performed with HotStarTaq Plus Master Mix Kit (Qiagen, Valencia, CA, country) for 30 cycles of the following conditions: $94{ }^{\circ} \mathrm{C}(3 \mathrm{~min}), 94{ }^{\circ} \mathrm{C}(30 \mathrm{sec}), 53{ }^{\circ} \mathrm{C}(40 \mathrm{sec}), 72{ }^{\circ} \mathrm{C}$ (1 $\mathrm{min})$ and a final extension at $72{ }^{\circ} \mathrm{C}(5 \mathrm{~min})$.

Raw sequence reads were processed and analyzed using the MOTHUR software (v. 1.39.5) [43] After trimming barcodes and primer sequences, quality control was performed through the 'screen.seqs' command and sequences were removed according to the following filtering parameters: length less than $250 \mathrm{bp}$, ambiguous bases, average quality score less than 25 , and homopolymers longer than eight nucleotides. Thereafter, the remaining sequences were aligned against the SILVA 132 database [44]. The VSEARCH algorithm was used to detect and remove chimeric reads. Sequences were clustered into operational taxonomic units (OTUs) based on the average neighbor algorithm at a $97 \%$ sequence identity threshold [45]. High-quality OTU sequences were classified to different taxa according to the SILVA 132 database [44] with confidence value set above $80 \%$.

\subsection{Statistical Analysis}

Values are presented as means \pm standard error of the mean (S.E.M.). Data were tested for normality and homogeneity with Kolmogorov-Smirnov and Levene' s tests, respectively. To determine any significant differences between different feeding frequencies treatments, one-way ANOVA was used, followed by Tukey's post-hoc test. Independent $t$-tests were considered statistically significant at $p<0.05$. Statistical analyses were carried out using the software package IBM SPSS Statistics V22.

\section{2. Results}

\subsection{Abiotic Factors}


Temperature was kept constant at $20^{\circ} \mathrm{C}$ for each aquarium. The mean $\mathrm{pH}$ value was $6.75 \pm 0.07,6.76 \pm 0.07$ and $6.77 \pm 0.70$ for FF2, FF4 and FF8 respectively, while the dissolved oxygen levels were $8.59 \pm 0.05 \mathrm{mg} / \mathrm{L}, 8.50 \pm 0.06 \mathrm{mg} / \mathrm{L}$ and $8.52 \pm 0.06 \mathrm{mg}$ / L, respectively (Table1). In all aquaponic systems the electrical conductivity was $1.28 \pm$ $0.006 \mathrm{mS} / \mathrm{cm}$ while the average salinity was $0.64 \pm 0.01 \mathrm{ppt}$ (Table 1). There were no significant differences $(\mathrm{p}>0.05)$ in the means of $\mathrm{NH}_{4}{ }^{+}, \mathrm{NH}_{3}, \mathrm{NO}_{3}^{-}, \mathrm{PO}_{4}{ }^{3-}$ and $\mathrm{pH}$ concerning the water quality in all of the 3 systems (Table1, Table 2).

The $\mathrm{NH}_{4}{ }^{+}, \mathrm{NH}_{3}, \mathrm{NO}_{3}{ }^{-}$and $\mathrm{PO}_{4}{ }^{3-}$ fluctuation at the water inlet point (GBin) and at the exit point (GBout) of the hydroponic cultivation tank is shown in Figure 2 respectively for all of the three systems.

Hydraulic loading rate $(H L R)$, the recirculation rate $(r)$, the retention time of the water into the filter bed $(H R T)$, the flow rate $(Q)$, ammonia production rate $\left(P_{\text {TAN }}\right)$ the specific surface area of the filter bed (SSA), the volume of filter media $\left(V_{\text {filter media }}\right)$ and the filter volume $\left(V_{\text {fitter }}\right)$ summarized in Table 3 were not statistically different $(p>0.05)$.

\subsection{Fish growth performance, histology and midgut microbiota}

The fish growth performance is illustrated in Table 4. At the start of the study, there were no significant differences in the means of sea bass initial body weight (gr) and length $(\mathrm{cm})$, (t-test, $p>0.05$ ) for all the feeding frequencies groups (Table 4). At the end of the 45-days study period FF2 group showed significant lower final weight, weight gain, specific growth rate and final length than FF4 and FF8 groups, $(p<0.05)$, (Table 4). Voluntary feed intake and FCR was similar for all the three feeding frequencies ( $p>0.05$ ), (Table 4). Survival rate for FF2, FF4 and FF8 was $77.2 \pm 25.96 \%, 96.5 \pm 1.75 \%$, and $96.5 \pm 1.75 \%$ respectively.

Liver histopathology of all the feeding frequency groups revealed mild (grade 2) accumulation of lipid droplets in liver cells with some of the nuclei of the liver cells to be pushed by the lipid droplets to the edge of the cells (Table 5, fig.3). Midgut and kidney microscopic examination showed no histopathological alterations (grade 0 ) in any of the feeding frequency groups (Table 4, fig. 3, 4). Minimal (grade 1) gill histopathological alterations were detected in FF2 and FF4 groups (Table 5), while mild (grade 2) histopathological alterations were detected in FF8 group (Table 5). Epithelium detachment at the secondary lamellae and hyperplasia of primary lamellae were detected in some cases of all the 3 groups (fig. 4).

A total of 2506 bacterial operational taxonomic units (OTUs) were found in all samplings. The lowest number of OTUs occurred on day $0(106 \pm 36.0)$. The average number of OTUs on days 15 and 45 ranged between $232 \pm 166.7$ and $467 \pm 129.0$. Permutanional Analysis of Variance (PERMANOVA) of the OTUs relative abundance indicated that there were no statistically significant differences between sampling points and feeding frequency (Table 6). 
4. Discussion

The plant growth characteristics are presented in Table 7. At the end of the 45days study period, plants in all systems exhibited similar leaf fresh weight, total fresh weight of leaves, total fresh and dry aerial biomass (Table 7). Nevertheless, plants in system 2 showed inferior root growth and significantly lower number of leaves compared to system 1 and 3 (Table 7). Additionally, plants in system 3 significantly outweigh all the others in stem length.

\subsection{Abiotic Factors}

In the present study an experimental aquaponic system for Mediterranean fish (sea bass) and a vegetable (lettuce) was studied for a duration of 45 days. To the authors' knowledge, this is one of a few studies using sea bass in aquaponic systems [46-48] and the first one to use three different feeding frequencies per day in the same aquaponic system. A successful aquaponic system provides important benefits, such as water quality control, high fish and plant growth performances, plant and fish disease management, and eliminating environmental impacts [36]. Such systems require less than $5 \%$ of freshwater to be renewed due to evaporation or losses from daily functioning $[49,50]$. Plant growth and production are indirectly related to feeding strategies, fish metabolic condition and microbial activity. Feeding rate and frequency affects nutrient availability in solution inside the system. Increased feeding frequency for fish contributes to more efficient plant nutrition $[27,51]$ as amounts of nitrate are available to the water for a longer period during the day.

The present study showed that the adaptation of sea bass in a fresh water aquaponic system together with cultivation of leafy vegetable lettuce is possible. Sea bass is an euryhaline specie. Direct transfer from sea to freshwater shows increased mortality [32, 52]. However, fish gradually adapted over a period of one month [38] do not show any mortality.

In an aquaponic system, the water temperature setting is dependent on the fish and plant species. Aquarium heater thermostats are used often in order to adjust the water temperature for the best growth of both plants and fish. For sea water-cultured sea bass, temperatures $19-22{ }^{\circ} \mathrm{C}$ show the maximum food utilization and growth rate $[53,54]$. According to Barnabé [55] and Lanari et al. [56], higher weight gain can be achieved for sea bass at temperatures between $22-28{ }^{\circ} \mathrm{C}$. In the present study, water temperature was kept constant at $20^{\circ} \mathrm{C}$, meeting the requirements of both sea bass and lettuce plants. The management of $\mathrm{pH}$ is also necessary in aquaponic systems. Plants, fish and bacteria require different $\mathrm{pH}$ ranges. Plants require a $\mathrm{pH}$ value between 5.5 and 
4046.5 to enhance the uptake of nutrients, and the optimal $\mathrm{pH}$ range for bacteria is $7.0-8.0$, 405 while the recommended $\mathrm{pH}$ for aquaculture is $6.5-8.5$ [11]. So, an optimal $\mathrm{pH}$ range for 406 an aquaponic system appears to be 6.5-7.0. $\mathrm{pH}>7.0$ can cause reduced solubility of 407 phosphorus and micronutrients. Plant uptake of certain nutrients is restricted in the 408 aquaponic environment [57]. In our study, $\mathrm{pH}$ showed a downward trend for all the three

409

410

411

412

413

414

415

416

417

418

419

420

421

422

423

424

425

426

427

428

429

430

431

432

433

434

435

436

437

438

439

440

441

442

443

444

445

446 feeding frequencies with mean values of 6.75-6.77. This downward trend is not unexpected, as the accumulation of nitrates (effective oxidation of ammonia) tends to make the aquatic environment more acidic. The mean value of $\mathrm{pH}$ is lower than 7.0 and within the tolerance levels for aquaponics. It is obvious that both $\mathrm{pH}$ and temperature are important parameters for the optimization of aquaponic production both for fish welfare/health issues and for plant needs.

Dissolved oxygen (DO) is the primary water quality consideration for aquaponic systems as in other aquaculture units. Oxygen levels of $7-8 \mathrm{mg} / \mathrm{L}$ ensure adequate ventilation for sea bass respiration [25, 35], while oxygen levels $>5 \mathrm{mg} / \mathrm{L}$ strengthen the plant's root system, nutrient uptake as well as the nitrification process [58, 59]. In general, the recommended limit for DO levels in fish culture is $6 \mathrm{ppm}$ for cold water fish and $4 \mathrm{ppm}$ for warm water fish [60].

The higher concentrations of $\mathrm{NH}_{3}, \mathrm{NH}_{4}{ }^{+}$and $\mathrm{NO}_{3}{ }^{-}$at the inlet point (GBin) than at the exit point (GBout) of the hydroponic cultivation tank indicate that the lettuce plants absorbed nutrients through the water. According to Von Wiren et al. [61], the nitrogen form that plants absorb depends on the temperature. Low temperatures generally increased the reliance of plants on ammonium as a mineral nitrogen source. Buzdy et al. [3] reported higher ammonia $\left(\mathrm{NH}_{4}{ }^{+}\right.$and $\left.\mathrm{NH}_{3}\right)$ removal than nitrate by lettuce in an aquaponic system. Xu et al. [62] determined that ammonium was the preferred nitrogen source when nitrogen concentrations were low, while nitrate was preferred when concentrations were high. In the present study, all forms of nitrogen $\left(\mathrm{NH}_{3}, \mathrm{NH}_{4}{ }^{+}\right.$and $\mathrm{NO}_{3}{ }^{-}$) at the exit point of the hydroponic cultivation tank exhibited lower concentrations after the $29^{\text {th }}$ day (fig. 2), indicating better absorbance from the lettuce plants after this day. In general, there were no major differences between the inlet point and exit point (fig. 2). This is in accordance with the fact that lettuce has low ability to remove inorganic nitrogen [3]. Phosphate absorbance increased after the $32^{\text {nd }}$ day (fig. 2). According to Buzby et al. [3], phosphate removal rates are increased when the plants are young and decrease over time. The type of substrate (clay pebbles) may affect the measurement of the nutrient concentrations at the exit point of the hydroponic cultivation tank. According to Meinken [63], nutrients can be absorbed (through diffusion) by clay pebbles and can be released back into the water circulation. This can be clearly seen from the $21^{\text {st }}-28^{\text {th }}$ days, when both nitrate and phosphate concentrations were higher at the exit point than the inlet point (Supp. fig. 2). In the 0-14 day time period, the phosphate concentration was also higher at the exit point than the inlet point (fig. 2). The gradual rise of nitrate levels proved the efficiency of the filter in oxidizing the produced ammonia. In the present study, the daily supply of $20-25 \mathrm{gr}$ of 
447 fish food efficiently provides the necessary nutrients for plants. During the experiment, 448 the water supply $(\mathrm{Q})$ was adjusted to $6.27 \mathrm{~L} / \mathrm{min}$ and the filtering speed $(\mathrm{V})$ to 1.79 $\mathrm{cm} / \mathrm{min}$, ensuring the successful nitration and maximum efficiency of the filter [64].

The mean hydraulic loading rate (HLR) and hydraulic retention time (HRT) for all aquaponic systems ranged from 0.95 to $0.96 \mathrm{~m} / \mathrm{d}$ and 7.46 to $7.49 \mathrm{~min}$, respectively, indicating the efficiency of the filter performance and the nutrient removal efficiency. The HRT impacts on the ammonia removal efficiency, alkalinity production, sulphate production and $\mathrm{C} / \mathrm{N}$ ratio in the denitrification process $[65,66]$. HLR impacts on fish and plant production and nutrient removal [48]. According to Chen et al. [67] the best HLR for freshwater aquaponic systems is $1.28 \mathrm{~m} /$ day. Endut et al. [12] reported that better growth performance of fish in a freshwater aquaponic system was observed at a higher HLR $(2.56 \mathrm{~m} / \mathrm{d})$ than the HLR used in the present study. Nevertheless, Vlahos et al. [36] reported that better growth performance of gilthead seabream and rock samphire was observed at an HLR of $1.84 \mathrm{~m} / \mathrm{d}$, which was higher than the HLR of the present study. The hydraulic loading rate (HLR) affects the production process of plants and fish and the daily nutrient removal efficiency and influences the contact time of the nutrients and microbial communities in the plants that grow in the bed [12,38]. High values of HLR affect nutrient cycling in the hydroponic tank and reduce the nutrient contact time with bacteria in contrast with a lower HLR [68].

According to El-Sayed and Kawanna [69], photoperiod is a factor that has a direct effect on the selected crop and does not exert a significant effect on fish growth. Liang \& Chien [27] came to a different conclusion. An increased photoperiod (24 hours of lighting) leads to increased fish growth compared to 12 hours of lighting [27]. A high light intensity and long photoperiod can favour both plant and fish growth and can improve water quality [70-72]. In the present study, the photoperiod was adjusted to 10 hours of light and 14 hours of darkness, simulating the winter season and enhancing lettuce growth [73].

\subsection{Fish growth performance, histology and gut microbiota}

During the 45-day trial period, the fish food was distributed throughout the day (24 hours). Sea bass is an easily adjustable species in different feeding habitats [74]. According to Sanchez-Vazquez et al. [75], sea bass show seasonal preference in feeding hours, preferring the morning during spring and summer and the evening during winter. Azzaydi et al. [76] showed higher SGR and lower FCR in night feeding during the winter months $(0.26 \pm 0.01 \% /$ day and $2.65 \pm 0.08$, respectively) in an RAS system compared to morning feeding $(0.19 \pm 0.01 \%$ /day and $3.73 \pm 0.17$, respectively).

The feeding frequency did not affect fish survival, with $77.2 \pm 25.96 \%, 96.5 \pm 1.75 \%$, and $96.5 \pm 1.75 \%$ survival being observed under the FF2, FF4 and FF8 treatments, respectively. On the day $16^{\text {th }}$ an unexplained fish mortality was observed (10 fish) for the FF2 group. This was probably due to anaesthesia fish handling. According to 
490 Gilderhus and Marking [77], the margin between the effective and toxic concentrations 491 of MS-222 tends to be narrow. Consequently, the observed mortality had no relation 492 with the feeding procedures. In sea bass, a feeding frequency of 1-3 meals per day 493 can deliver good growth and FCR performance [35, 78]. For juvenile's sea bass (5.2-6.8 $494 \mathrm{~g}$ ) a feeding frequency of two times per day seems to be the minimum with good growth 495 results and was followed to previous studies [79-81]. Nevertheless, in this study feeding 496 frequency of 2,4 and 8 meals per day was tested in order to examine how it affects the 497 daily nitrate fluctuation for better plant nutrition in an aquaponic system. In a study by 498 Biswas et al. [25], Asian sea bass fed 1, 2, 3 and 4 times a day in brackish water (3.2$4.1 \%$ ) showed the highest survival at 3 times $(75.89 \pm 4.17 \%)$ compared to other treatments. Similar results were reported for the fish species Epinephelus tauvina, Aristichthys nobilis and Sparus aurata [82-84]. Vlahos et al., [36] working with Sparus aurata in an RAS aquaponic system under the salinities of $8 \%$ and $20 \%$ and a feeding frequency of 3 times per day, reported survival rates of $99 \%$ and $97 \%$, respectively. In the present study, the survival rate of FF2, FF4 and FF8 feeding frequency treatment were higher than those for Asian sea bass and Aristichthys nobilis [25, 83]. The survival rates under FF4 and FF8 were similar to those reported for Epinephelus tauvina and Sparus aurata [38, 82, 84].

In an RAS and consequently in an aquaponic system, a properly selected diet must be managed in such a way as to meet the nutritional requirements of different fish and plant species. By selecting the appropriate food amount per day and appropriate feeding frequency, metabolic products (excretions) are reduced, fish growth is enhanced, and water quality ultimately improves [27]. The removal of fish metabolic products (nutrients) from the water is directly related to the quantity of the provided diet, the feeding frequency and the food quality. Nitrogen content in fish faeces ranges (10 to $40 \%$ ), depending on the nitrogen content of the provided diet and the fish type [85]. In the present study, fish were fed daily at $5 \%$ of their body weight with a commercial floating pellet diet (55\% protein and $15 \%$ crude fat), showing good growth for all of the feeding frequency groups. These results suggest that the provided food amount was appropriate, and they are in agreement with those of Eroldogan et al. [34], where sea bass with an initial weight $2.6 \pm 0.3 \mathrm{~g}$ cultured in seawater $(40 \mathrm{ppm})$ and in fresh water (0.4 ppm) with six different feeding rates $(2 \%, 2.5 \%, 3 \%, 3.5 \%, 4 \%$, saturation) showed greater WG and SGR in fresh water and at a feeding rate of $3.5 \%$ until saturation. Türkmen et al. [86] also showed that sea bass fed at $5 \%$ of their body weight 4 and 8 times per day exhibited a higher SGR. In contrast, Waller et al. [46], working with sea bass fed daily to satiation, showed a lower SGR and FCR ( $1.5 \%$ and 0.93 respectively).

In aquaponic systems, increased feeding frequency seems to have positive effects on fish and plant growth. Liang and Chien [27], working in a tilapia-water spinach aquaponic system, reported that increasing feeding frequency increased both fish and plant production and lessened the accumulation of nitrogen and phosphorus nutrients in water. The same results were reported by Mohamed Abdelrahman [51] while studying 
533 the effect of different daily fish feeding frequencies (1,2 and 3 times per day) in a tilapia 534 and lettuce aquaponic system. In the present study, the higher WG, SGR and were 535 achieved at FF4 and FF8 (no significant differences were detected between these two 536 feeding frequencies). FCR and voluntary feed intake did not differ among the three 537 feeding frequencies $(p>0.05)$. Feeding four or eight times per day seems to have the best effects on fish growth. This result is in accordance with Biswas et al. [25], who showed that Asian sea bass (Lates calcarifer) cultured in brackish water had the best SGR when it was fed 3 or 4 times per day.

It is not clear if salinity is an important factor for the optimal growth of euryhaline species, as it is a disagreement among researchers if acclimatization to fresh water can cause a loss of appetite, increased mortality and decrement of conversion efficiency [31, 87-89] or can cause similar or even better growth parameters than sea water [47, 90-92]. Eroldogan and Kumlu [90] showed that sea bass juveniles cultured in fresh water, 10 and 20 ppt grew better than those at 30 or 40 ppt. In a second experiment of the same study [90], young sea bass grown in fresh water had higher WG than those grown in sea water, with a slightly higher FCR in sea water. Vlahos et al. [36] did not detect differences in the growth performance of seabreams in two different salinities (8 ppt and 20 ppt). Nozzi et al. [47] showed higher WG and SGR for sea bass in fresh water than in sea water. Even at extreme temperatures, sea bass seems to grow better in low salinity water. According to Islam et al [91], sea bass reared for 35 days followed by 10 days of extreme warm temperature $\left(33^{\circ} \mathrm{C}\right)$ showed higher weight gain and SGR at $12 \%$ and $6 \%$ salinity water than at $32 \%$. Weight gain and SGR were similar in $32 \%$ and $2 \%$ salinity (8.45 g and $9.42 \mathrm{~g}$ weight gain, respectively, and 2.03 and $1.93 \mathrm{SGR}$, respectively). In our study, SGR was $2.11,2.23$ and 2.36 , while weight gain was 10.66 $\mathrm{g}, 13.14 \mathrm{~g}$, and $13.85 \mathrm{~g}$ under FF2, FF4, and FF8, respectively. These values are higher than those reported by Islam et al [91], probably because no temperature stress occurred. Yilmaz et al. [92], in a 60-day trial of the growth performance of sea bass in fresh water $\left(0 \%\right.$ salinity, $\left.20^{\circ} \mathrm{C}\right)$, reported a $1.1 \%$ SGR and $1.2 \mathrm{FCR}$, which SGR to be lower than the values in our study but FCR to be similar with our value in FF8 group.

Kidney is an important organ for the osmoregulation of euryhaline fish [93, 94]. Fish like sea bass, trout, herring, and juvenile seabream show good adaptation to salinity changes, surviving this way in both seawater and freshwater. Nebel et al. [30], reported that sea bass juveniles lived in freshwater had smaller collecting ducts than those lived in seawater. Vlahos et al. [36], when adapting seabream to lower salinity (8 ppt), did not detect histopathological alterations of the midgut, smaller collecting ducts, granulomas or dilation of Bowman space in the kidney, hyperplasia of primary/secondary lamellae or epithelial detachment of the secondary lamella in gills, while liver histopathology showed inflammation and steatosis. In the present study, midgut and kidney microscopic examination showed no histopathological alterations, while liver showed mild accumulation of lipid droplets, and the gills showed mild epithelial detachment at the secondary lamellae and mild hyperplasia of the primary lamellae. Similar results for gills were reported in previous studies [95, 96], thus indicating the high plasticity and gill remodelling of sea bass adapted from seawater to 
578 freshwater. Lipid accumulation in the liver seems to be more extensive in sea bass 579 living in sea water than in sea bass acclimatized to fresh water [47].

580 The management of the aquaponics systems' water quality in order to meet the requirements of both reared fish and cultivated crops is not easy [97]. According to Yavuzcan Yildiz et al. [11], a high level of suspended solids can affect the health status of fish, provoking damage to the gill structure, such as epithelial detachment, hyperplasia, lamella fusion and reduction of epithelial volume. Feed waste includes both dissolved components (phosphorus and nitrogen-based nutrients) and suspended solids. Our results are similar to those reported by Yavuzcan Yildiz et al. [11]. Uneaten food and faeces were removed daily by siphoning, but a breakdown in small particles still occurred. These particles are potentially dangerous and very difficult to collect. According to Lekang [98], the small particles will normally dominate in re-use systems.

Feeding frequency had no statistically significant impact $(p=0.105)$ on the structure of the midgut microbiota, indicating a minimal observable impact on the sea bass gut bacterial community. In this study, we analysed the resident midgut microbiota, i.e., bacteria that replicate inside the host's gut tissue cells, and not the transient bacteria associated with the animal's digesta [99]. Moreover, it has been recently shown that even nutritionally similar diets in sympatrically reared fish species cannot override host genetics in shaping the resident gut microbiota [100]. Thus, the resident microbiota is expected to be less variable with pulses in the feed supply, as was the case in our study. However, small qualitative differences in the structure of gut bacterial communities have been reported for other fish after a short period after a single meal[101], and this remains to be investigated for freshwater-adapted sea bass.

\subsection{Plant growth performance}

The successful cultivation of various plant species, including herbs, fruiting crops and leafy vegetables, in aquaponics has been well documented during the last decade of intensive relevant research. Lettuce is one of the most commonly studied species, mainly because it is a widely consumed vegetable worldwide with low to medium nutritional requirements, a short harvest period and its cultivation is convenient in terms of light and space [58]. Many studies have examined the performance of lettuce in aquaponic systems and furthermore have compared it with hydroponics and complemented aquaponics [102]. To the best of our knowledge, there are only two published experiments concerning the effect of the fish feeding frequency on lettuce growth [51, 72]. In an early study, Rakocy et al. [72] concluded that a higher fish feeding frequency had a positive effect on lettuce growth in aquaponics. In accordance with this finding, Mohamed Abdelrahman [51] reported that an increased feeding frequency contributes to a more efficient nutrient supply to lettuce. The outcome was a $13.7 \%$ increase in lettuce production $\left(\mathrm{kg} / \mathrm{m}^{2}\right)$ when tilapias were fed thrice per day in comparison with once per day. 
622

623

624

625

626

627

628

629

630

631

632

633

634

635

636

637

638

639

640

641

642

643

644

645

646

647

648

649

650

651

652

653

654

655

656

657

658

659

660

Despite the large number of published works involving lettuce in aquaponic systems, it is usually difficult to attempt comparisons of growth responses, mainly due to different experimental set-ups and physicochemical parameters, which greatly affect the results. Under this framework, the results of the present study concerning total fresh biomass production $\left(3.22-3.97 \mathrm{~kg} / \mathrm{m}^{2}\right)$ are intermediate between the low lettuce production of $47.9 \mathrm{~g} / \mathrm{m}^{2}$ reported by Castillo-Castellanos et al. [103] and the values of $4.97 \mathrm{~kg} / \mathrm{m}^{2}$ obtained in the study of Lennard and Leonard [73]. In the first case, the experiment included a tilapia-lettuce cultivation system (tilapia stocking density $7 \mathrm{~kg} / \mathrm{m}^{3}$, fed 4 times per day $3.5 \%$ of body weight), and in the second involved the cultivation of lettuce and Murray cod (feeding rate of $1-1.5 \%$ of body weight, $43 \%$ protein) for 21 days. The same growth period of 21 days in the work of Dediu et al. [40] yielded similar lettuce production as our system, though the latter lasted 45 days and was conducted with a 6 times-lower initial fish density. It is well established that different variants of the same plant species can react differently even though growth conditions are identical. Andriani et al. [6] (2017) co-cultivated lettuce and mixed fish species (catfish and Nile tilapia fed with $31-33 \%$ protein, $4 \%$ of body weight) for 49 days. They reported final fresh aerial biomass similar to the results of the present study, yet the different lettuce variety resulted in discrepancies in other growth characteristics due to the different plant architecture.

\section{Conclusions}

This study highlights the use of economic important euryhaline fish, such as sea bass, in a fresh water aquaponics system for the production of high-demand plants, such as lettuce. This combined cultivation can have a positive effect on the increase of food production and food security. Increased fish feeding frequency can have a positive benefit to the combined cultivation, as it can lead to improved fish growth parameters and to an increased plant biomass. The production of high commercial and nutritional value foods along with the achievement of high-quality food production through aquaponics systems may not be far away.

\section{Acknowledgements}

This research has been co-financed by the European Union and Greek national funds through the Operational Program Competitiveness, Entrepreneurship and Innovation, under the call RESEARCH - CREATE - INNOVATE (project code:T1EDK--01153).

Author contribution

P.B and E.M. designed the study. P.S., N.V., P.B. performed the experiments. K.A.K., E.N., E.M. performed the microbiome analysis and P.B., P.S. the histology analysis. 
661 P.S., P.B., E.L. N.K. performed the data analysis. P.B. N.K., E.M. drafted the 662 manuscript. All authors checked and approved the final version of the manuscript.

663

664

6. References

665

666

667

1. Tyson, R. V., Treadwell, D. D. \& Simonne, E. H. Opportunities and challenges to sustainability in aquaponic systems. HortTechnol. 21, 6-13 (2011).

668

669

670

671

672

673

674

675

676

677

678

679

680

681

682

683

684

685

686

687

688

689

690

691

692

693

694

695

696

697

698

699

700

2. Blidariu, F. \& Grozea, A. Increasing the economical efficiency and sustainability of indoor fish farming by means of aquaponics-review. Sci. Pap. Anim. Sci.

Biotechnol. 44, 1-8 (2011).

3. Buzby, M. K. \& Lin, L.S. Scaling aquaponic systems: Balancing plant uptake with fish output. Aquac. Eng. 63, 39-44 (2014).

4. Bittsanszky, Andras, Nikolett Uzinger, Gabor Gyulai, Alex Mathis, Ranka Junge, Morris Villarroel, Benzion Kotzen, and Tamás Kőmíves. "Nutrient supply of plants in aquaponic systems." Ecocycles 2, no. 2 (2016): 17-20.

5. Nuwansi, K. K. T., Verma, A. K., Prakash, C., Tiwari, V. K., Chandrakant, M. H., Shete, A. P., \& Prabhath, G. P. W. A. (2016). Effect of water flow rate on polyculture of koi carp (Cyprinus carpio var. koi) and goldfish (Carassius auratus) with water spinach (Ipomoea aquatica) in recirculating aquaponic system. Aquaculture international, 24(1), 385-393.

6. Andriani, Y., Dhahiyat, Y., Zahidah, Z. \& Zidni, I. The effect of stocking density ratio of fish on water plant productivity in aquaponics culture system. Nusant. Biosci. 9, 31-35 (2017).

7. Diver, S. Aquaponics-Integration of Hydroponics with Aquaculture, National Sustainable Agriculture Information Service. (ed. Driscoll, P.) 28 (ATTRA,2006)

8. Saha, S., Monroe, A. \& Day, M. R. Growth, yield, plant quality and nutrition of basil (Ocimum basilicum L.) under soilless agricultural systems. Ann. Agricult. Sci. 61, 181-186 (2016).

9. Knaus, U. \& Palm, H. W. Effects of the fish species choice on vegetables in aquaponics under spring-summer conditions in northern Germany (Mecklenburg Western Pomerania). Aquac. 473, 62-73 (2017). 
10. Francis-Floyd, R., Watson, C., Petty, D. \& Pouder, D. Ammonia in Aquatic Systems. Department of Agriculture, Cooperative Extension Service, University of Florida, IFAS (2012)

11. Yavuzcan Yildiz, H., Robaina, L., Pirhonen, J., Mente, E., Domínguez, D., Parisi, G. Fish Welfare in Aquaponic Systems: Its Relation to Water Quality with an Emphasis on Feed and Faeces-A Review. Water 9, 1-17 (2017).

12. Endut, A., Jusoh, A., Ali, N., Nik, W. W. \& Hassan, A. A study on the optimal hydraulic loading rate and plant ratios in recirculation aquaponic system. Bioresour. Technol. 101, 1511-1517 (2010).

13. Rakocy, J. E., Shultz, R. C., Bailey, D. S. \& Thoman, E. S. Aquaponic production of tilapia and basil: comparing a batch and staggered cropping system. Acta Hortic. 648, 63-69 (2004).

14. Buzby, K. M., Waterland, N. L., Semmens, K.J. \& Lin, L. S. Evaluating aquaponic crops in a freshwater flow-through fish culture system. Aquac. 460, 15-24 (2016).

15. Rakocy, J.E. (2007). Ten Guidelines for Aquaponic Systems. Aquaponics J., 1, $14-17$.

16. Cai, Y., Wermerskirchen, J. \& Adelman, I. R. Ammonia excretion indicates protein adequacy for fish. Prog. Fish Cult. 58, 124-127 (1996).

17. Robaina, L., Pirhonen, J., Mente, E., Sánchez, J. \& Goosen, N. Fish Diets in Aquaponics. In Aquaponics Food Production Systems. 333-352 (Springer, Cham, 2019).

18. Lazo, J. P., Davis, D. A. \& Arnold, C. R. The effects of dietary protein level on growth, feed efficiency and survival of juvenile Florida pompano (Trachinotus carolinus). Aquac. 169, 225-23 (1998).

19. Jobling, M. Fish bioenergetics. Oceanograph. Lit. Rev. 9, 785 (1995).

20. Medina, M., Jayachandran, K., Bhat, M. G. \& Deoraj, A. Assessing plant growth, water quality and economic effects from application of a plant-based aquafeed in a recirculating aquaponic system. Aquac. Int. 24, 415-427 (2016).

21. Kaushik, S. J. Influence of the nutritional status on the daily pattern of nitrogen excretion in the carp (Cyprinus carpio L.) and the rainbow trout (Salmo gairdneri R.). Reprod. Nut. Develop. 20, 1751-1765 (1980). 
22. Gelineau, A., Medale, F. \& Boujard, T. Effect of feeding time on postprandial nitrogen excretion and energy expenditure in rainbow trout. J. Fish Biol. 52, 655664 (1998).

23. Cho, S. H. et al. Effects of feeding rate and feeding frequency on survival, growth, and body composition of Ayu post-larvae Plecoglossus altivelis. J. World Aquac. Soc. 34, 85-91 (2003).

24. Silva, C. R., Gomes, L. C. \& Brandão, F. R. Effect of feeding rate and frequency on tambaqui (Colossoma macropomum) growth, production and feeding costs during the first growth phase in cages. Aquac. 264, 135-139 (2007).

25. Biswas, G., Thirunavukkarasu, A. R., Sundaray, J. K. \& Kailasam, M. Optimization of feeding frequency of Asian seabass (Lates calcarifer) fry reared in net cages under brackish water environment. Aquac. 305, 26-31 (2010).

26. Steingrover, E., Ratering, P. \& Siesling, J. Daily changes in uptake, reduction and storage of nitrate in spinach grown at low light intensity. Physiol. Plant. 66, 555-556 (1986).

27. Liang, J. Y. \& Chien, Y. H. Effects of feeding frequency and photoperiod on water quality and crop production in a tilapia-water spinach raft aquaponics system. Int. Biodeterior. Biodegrad. 85, 693-700 (2013).

28. Federation of Greek Maricultures (2019) Annual report 2019. https://www.fgm.com.gr. (Accessed 20 March 2020)

29. Pickett, G. D. \& Pawson, M. G. Sea Bass: Biology. (Springer Sci \& Business Media, 1994)

30. Nebel, C., Romestand, B., Nègre-Sadargues, G., Grousset, E., Aujoulat, F., Bacal, J., Bonhomme, F., \& Charmantier, G. (2005). Differential freshwater adaptation in juvenile sea-bass Dicentrarchus labrax: involvement of gills and urinary system. J. Exp. Biol. 208, 3859-3871.

31. Allegrucci, G., Fortunato, C., Cataudella, S. \& Sbordoni, V. Acclimation to freshwater of the sea bass-evidence of selective mortality of allozyme genotypes. In Genetics and Evolution of Aquatic Organisms Conference. (Chapman \& Hall) 486-502 (Bangor Wales, 1994) 
786

787

788

789

790

791

792

793

794

795

796

797

798

799

800

801

802

803

804

805

806

807

808

809

810

811

812

813

814

815

816

817

818

819

820

821

822

823

824

825

826

827

32. Dendrinos, P. \& Thorpe, J. P. Effects of reduced salinity on growth and body composition in the European bass Dicentrarchus labrax (L.). Aquac. 49, 333-358 (1985).

33. Jensen, K., Madsen, S. S. \& Kristiansen, K. Osmoregulation and salinity effects on the expression and activity of $\mathrm{Na}+, \mathrm{K}+$-ATPase in the gills of European sea bass, Dicentrarchus labrax (L.). J. Exp. Zool. 282, 290-300 (1998).

34. Eroldoğan, O. T. Optimum feeding rates for European sea bass Dicentrarchus labrax L. reared in seawater and freshwater. Aquac. 231, 501-515 (2004).

35. Güroy, D. et al. Replacement of fishmeal with rice protein concentrate in practical diets for European seabass Dicentrarchus labrax reared at winter temperatures. Aquacult. Res. 44, 462-471 (2013).

36. Vlahos, N., Levizou, E., Stathopoulou, P., Berillis, P., Antonopoulou, E., Bekiari, V., Krigas, N., Kormas, K., \& Mente, E. (2019). An Experimental Brackish Aquaponic System Using Juvenile Gilthead Sea Bream (Sparus aurata) and Rock Samphire (Crithmum maritimum). Sustainability, 11(18), 4820.

37. Hirayama, K. Water control by filtration in closed culture systems. Aquac. 4, 369385 (1974).

38. Marino, G., Cataldi, E., Pucci, P., Bronzi, P. \& Cataudella, S. Acclimation trials of wild and hatchery sea bass (Dicentrarchus labrax) fry at different salinities. J. Appl. Ichthyol. 10, 57-63 (1994).

39. Huguenin, J. \& Colt, J. Design and Operating Guide for Aquaculture Seawater Systems. (Elsevier, Amsterdam, 2002).

40. Dediu, L., Cristea, V. \& Xiaoshuan, Z. Waste production and valorization in an integrated aquaponic system with bester and lettuce. Afr. J. Biotechnol. 11, 23492358 (2012).

41. Panteli, N. et al. Imprinting statistically sound conclusions for gut microbiota in comparative animal studies: A case study with diet and teleost fishes. Comp. Biochem. Physiol. Part D: Genomics and Proteomics 36, 100738 (2020).

42. Klindworth, A.; Pruesse, E.; Schweer, T.; Peplies, J.; Quast, C.; Horn, M.; Glöckner, F.O. Evaluation of General 16S Ribosomal RNA Gene PCR Primers 
for Classical and Next-Generation Sequencing-Based Diversity Studies. Nucleic Acids Res. 2013, 41, doi:10.1093/nar/gks808

43. Schloss, P.D.; Westcott, S.L.; Ryabin, T.; Hall, J.R.; Hartmann, M.; Hollister, E.B.; Lesniewski, R.A.; Oakley, B.B.; Parks, D.H.; Robinson, C.J.; et al. Introducing Mothur: Open-Source, Platform-Independent, Community-Supported Software for Describing and Comparing Microbial Communities. Appl. Environ. Microbiol. 2009, 75, 7537-7541, doi:10.1128/AEM.01541-09

44.Pruesse, E.; Quast, C.; Knittel, K.; Fuchs, B.M.; Ludwig, W.; Peplies, J.; Glöckner, F.O. Silva: A Comprehensive Online Resource for Quality Checked and Aligned Ribosomal RNA Sequence Data Compatible with ARB. Nucleic Acids Res. 2007, 35, 7188-7196, doi:10.1093/nar/gkm864.

45. Stackebrandt, E.; Goebel, B.M. Taxonomic Note: A Place for DNA-DNA Reassociation and 16S RRNA Sequence Analysis in the Present Species Definition in Bacteriology. Int. J. Syst. Evol. Micr. 1994, 44, 846-849, doi:10.1099/00207713-44-4-846.

46. Waller, $U$. et al. Integrated multi-trophic aquaculture in a zero-exchange recirculation aquaculture system for marine fish and hydroponic halophyte production. Aquac. Int. 23, 1473-1489 (2015).

47. Nozzi, V. et al. Amyloodinum ocellatum in Dicentrarchus labrax: Study of infection in salt water and freshwater aquaponics. Fish Shellfish Immunol. 57, 179-185 (2016a).

48. Nozzi, V., Parisi, G., Di Crescenzo, D., Giordano, M. \& Carnevali, O. Evaluation of Dicentrarchus labrax meats and the vegetable quality of Beta vulgaris var. cicla farmed in freshwater and saltwater aquaponic systems. Water 8, 423 (2016b).

49. Hu, Z. et al. Effect of plant species on nitrogen recovery in aquaponics. Bioresour. Technol. 188, 92-98 (2015).

50. Nozzi, V., Graber, A., Schmautz, Z., Mathis, A. \& Junge, R. Nutrient management in aquaponics: comparison of three approaches for cultivating lettuce, mint and mushroom herb. Agron 8, 27 (2018).

51. Mohamed Abdelrahman, A. A. Effect of Feeding Frequency and Stocking Density on Tilapia (Oreochromis niloticus) and Lettuce (Lactuca sativa) Production in Aquaponics System under the UAE Condition and Business Enterprise Analysis. Biology Theses in United Arab Emirates University. 
https://scholarworks.uaeu.ac.ae/bio_theses/1 (2018).

872

873

52. Cataudella, S. et al. Multidisciplinary approach to the optimisation of sea bass (Dicentrarchus labrax) rearing in freshwater - Basic morpho-physiology and osmoregulation. Aquac. Env. 14, 56-57 (1991).

53. Alliot, E., Pastoureaud, A. \& Thebault, H. Influence of temperature and salinity on growth and body composition of sea bass fingerlings, Dicentrarchus labrax. Aquac. 31, 181-194 (1983).

54.Zanuy, S. \& Carrillo, M. Annual cycles of growth, feeding rate, gross conversion efficiency and hematocrit levels of sea bass (Dicentrarchus labrax L.) adapted to two different osmotic media. Aquac. 44, 11-25 (1985).

55. Barnabé, G. Rearing bass and gilthead bream. Aquac. 2, 647-686 (1990).

56. Lanari, D., D’Agaro, E. \& Ballestrazzi, R. Growth parameters in European sea bass (Dicentrarchus labrax L.): effects of live weight and water temperature. Ital. J. Anim. Sci. 1, 181-185 (2002).

57.Tyson, R., Simonne, E., White, J. \& Lamb, E. Reconciling water quality parameters impacting nitrification in aquaponics: the ph levels. Proc. Fla. State Horticult. Soc. 117, 79-83 (2004).

58. Rakocy, J., Master, M. P. \& Losordo, T. M. Recirculating aquaculture tank production system : Aquaponics - integrating fish and plant culture. SRAC 454, (USDA 2006).

59. Graber, A. \& Junge, R. Aquaponic Systems: Nutrient recycling from fish wastewater by vegetable production. Desalination 246, 147-156 (2009).

60. Wedemeyer, G. A. Physiology of Fish in Intensive Culture Systems (Chapman \& Hall, USA, 1996).

61. Von Wirén, N., Gazzarrini, S. \& Frommer, W. B. Regulation of mineral nitrogen uptake in plants. Plant Soil 196, 191-199 (1997).

62. Xu, Q. F., Tsai, C. L. \& Tsai, C. Y. Interaction of potassium with the form and amount of nitrogen nutrition on growth and nitrogen uptake of maize. J. Plant Nutr. 15, 23-33 (1992). 
914

915

916

917

918

919

920

921

922

923

924

925

926

927

928

929

930

931

932

933

934

935

936

937

938

939

940

941

942

943

944

945

946

947

948

949

950

951

952

953

954

955
63. Meinken, E. Accumulation of nutrients in expanded clay used for indoor plantings. In International Symposium Growing Media and Plant Nutrition in Horticulture, 450, 321-328 (1996).

64. Shete, A. P. et al. Optimization of hydraulic loading rate in aquaponic system with Common carp (Cyprinus carpio) and Mint (Mentha arvensis). Aquac. Eng. 72, 5357 (2016).

65. Christianson, L., Lepine, C., Tsukuda, S., Saito, K. \& Summerfelt, S. Nitrate removal effectiveness of fluidized sulfur-based autotrophic denitrification biofilters for recirculating aquaculture systems. Aquac. Eng. 68, 10-18 (2015).

66. Suhr, K. I., Pedersen, P. B. \& Arvin, E. End-of-pipe denitrification using RAS effluent waste streams: Effect of $\mathrm{C} / \mathrm{N}$-ratio and hydraulic retention time. Aquac. Eng. 53, 57-64 (2013).

67. Chen, S., Ling, J. \& Blancheton, J. P. Nitrification kinetics of biofilm as affected by water quality factors. Aquac. Eng. 34, 179-197 (2006).

68. Gichana, Z. et al. Efficiency of pumpkin (Cucurbita pepo), sweet wormwood (Artemisia annua) and amaranth (Amaranthus dubius) in removing nutrients from a smallscale recirculating aquaponic system. Aquac. Int. 27, 1767-1786 (2019).

69. El-Sayed, A. F. M. \& Kawanna, M. Effects of photoperiod on the performance of farmed Nile tilapia Oreochromis niloticus: I. Growth, feed utilization efficiency and survival of fry and fingerlings. Aquac. 231, 393-402 (2004).

70. Liang, J. Y. \& Chien, Y. H. Effects of photosynthetic photon flux density and photoperiod on water quality and crop production in a loach (Misgurnus anguillicandatus) nest fern (Asplenium nidus) raft aquaponics system. Int. Biodeterior. Biodegrad. 102, 214-222 (2015).

71. Petrucio, M. M., \& Esteves, F. A. (2000). Influence of photoperiod on the uptake of nitrogen and phosphorus in the water by Eichhornia crassipes and Salvinia auriculata. Revista Brasileira de Biologia, 60(3), 373-379.

72. Rakocy, J. E., Bailey, D. S., Shultz, K. A., \& Cole, W. M. Evaluation of a commercial-scale aquaponic unit for the production of tilapia and lettuce. In Tilapia aquaculture: proceedings of the fourth international symposium on tilapia in aquaculture, Orlando, Florida 357-372 (1997). 
956

957

958

959

960

961

962

963

964

965

966

967

968

969

970

971

972

973

974

975

976

977

978

979

980

981

982

983

984

985

986

987

988

989

990

991

992

993

994

995

996
73. Lennard, W. A. \& Leonard, B. V. A comparison of three different hydroponic subsystems (gravel bed, floating and nutrient film technique) in an aquaponic test system. Aquac. Int. 14, 539-550 (2006).

74. Boujard, T., Jourdan, M., Kentouri, M. \& Divanach, P. Diel feeding activity and the effect of time-restricted self-feeding on growth and feed conversion in European sea bass. Aquac. 139, 117-127 (1996).

75. Sánchez-Vázquez, F. J., Azzaydi, M., Martinez, F. J., Zamora, S. \& Madrid, J. A. Annual rhythms of demand-feeding activity in sea bass: evidence of a seasonal phase inversion of the diel feeding pattern. Chronobiol. Int. 15, 607-622 (1998).

76. Azzaydi, M., Martınez, F.J., Zamora, S., Sánchez-Vázquez, F.J. \& Madrid, J.A. The influence of nocturnal vs. diurnal feeding under winter conditions on growth and feed conversion of European sea bass (Dicentrarchus labrax, L.). Aquac. $182,329-338$ (2000).

77. Gilderhus, P. A., \& Marking, L. L. (1987). Comparative efficacy of 16 anesthetic chemicals on rainbow trout. North American Journal of Fisheries Management, 7(2), 288-292.

78. Kousoulaki, K., Sæther, B. S., Albrektsen, S., \& Noble, C. (2015). Review on European sea bass (Dicentrarchus labrax, Linnaeus, 1758) nutrition and feed management: a practical guide for optimizing feed formulation and farming protocols. Aquaculture Nutrition, 21(2), 129-151.

79. Gasco, L., Henry, M., Piccolo, G., Marono, S., Gai, F., Renna, M., Lussiana, C., Antonopoulou, E., Mola, P. and Chatzifotis, S. (2016). Tenebrio molitor meal in diets for European sea bass (Dicentrarchus labrax L.) juveniles: growth performance, whole body composition and in vivo apparent digestibility. Animal Feed Science and Technology, 220, 34-45.

80.Peres, H., \& Oliva-Teles, A. (1999). Effect of dietary lipid level on growth performance and feed utilization by European sea bass juveniles (Dicentrarchus labrax). Aquaculture, 179(1-4), 325-334.

81. Peres, H., \& Oliva-Teles, A. (2002). Utilization of raw and gelatinized starch by European sea bass (Dicentrarchus labrax) juveniles. Aquaculture, 205(3-4), 287299. 
997

998

999

1000

1001

1002

1003

1004

1005

1006

1007

1008

1009

1010

1011

1012

1013

1014

1015

1016

1017

1018

1019

1020

1021

1022

1023

1024

1025

1026

1027

1028

1029

1030

1031

1032

1033

1034

1035

1036

1037

1038

1039
82. Thia-Eng, C. \& Seng-Keh, T. Effects of feeding frequency on the growth of young estuary grouper, Epinephelus tauvina (Forskål), cultured in floating net-cages. Aquac. 14, 31-47 (1978).

83. Carlos, M.H. Growth and survival of bighead carp (Aristichthys nobilis) fry fed at different intake levels and feeding frequencies. Aquac. 68, 267-276 (1988).

84. Goldan, O., Popper, D. \& Karplus, I. Management of size variation in juvenile gilthead sea bream (Sparus aurata). I: Particle size and frequency of feeding dry and live food. Aquac. 152, 181-190 (1997).

85. Van Rijn, J. Waste treatment in recirculating aquaculture systems. Aquacult. Eng. 53, 49-56 (2013).

86. Türkmen, S. et al. Compensatory growth response of $E$ uropean sea bass (D icentrarchus labrax L.) under cycled starvation and restricted feeding rate. Aquac. Res. 43, 1643-1650 (2012).

87.J. Chervinski, M. Lahav. Freshwater feed of young European sea bass [Dicentrarchus labrax (L.)]. Bamidgeh, 31 (1979), pp. 44-48.

88.S.S. De Silva, P.A.B. Perera. Studies on the grey mullet, Mugil cephalus L. I. Effects of salinity on food intake, growth and food conversion. Aquaculture, 7 (1976), pp. 327-338.

89.D.S. Peters. Growth and energy utilization of juvenile flounder, Paralichthys denatus and Parlichthys lethostigma, as affected by temperature, salinity and food availability. Ph.D. Thesis, North Carolina State University, Raleigh, NC (1971), p. 69

90. Eroldogan, O. T. \& Kumlu, M. Growth performance, body traits and fillet composition of the European sea bass (Dicentrarchus labrax) reared in various salinities and fresh water. Turk. J. Vet. Anim. Sci. 26, 993-1001 (2002).

91. Islam, M. J., Kunzmann, A., Thiele, R. \& Slater, M. J. Effects of extreme ambient temperature in European seabass, Dicentrarchus labrax acclimated at different salinities: Growth performance, metabolic and molecular stress responses. Sci. Total Environ. 735, 139371 (2020).

92. Yilmaz, H. A., Turkmen, S., Kumlu, M., Eroldogan, O. T. \& Perker, N. Alteration of growth and temperature tolerance of european sea bass (Dicentrarchus labrax linnaeus 1758) in different temperature and salinity combinations. Turkish J. Fish Aquat. Sci. 20, 331-340 (2020). 
1040

1041

1042

1043

1044

1045

1046

1047

1048

1049

1050

1051

1052

1053

1054

1055

1056

1057

1058

1059

1060

1061

1062

1063

1064

1065

1066

1067

1068

1069

1070

1071

1072

1073

1074

1075

1076

1077

1078

1079

1080

1081

1082
93. Greenwell, M. G., Sherrill, J., \& Clayton, L. A. (2003). Osmoregulation in fish. Mechanisms and clinical implications. The veterinary clinics of North America. Exotic animal practice, 6(1), 169-89.

94. Hammerschlag, N. (2006). Osmoregulation in elasmobranchs: a review for fish biologists, behaviourists and ecologists. Marine and Freshwater Behaviour and Physiology, 39(3), 209-228.

95. Laiz-Carrión, R. et al. Branchial osmoregulatory response to salinity in the gilthead sea bream, Sparus auratus. J. Exp. Zool. Part A Comp. Exp. Boil 303, 563-576 (2005).

96. Masroor, W., Farcy, E., Gros, R. \& Lorin-Nebel, C. Effect of combined stress (salinity and temperature) in European sea bass Dicentrarchus labrax osmoregulatory processes. Comp. Biochem. Physiol. Part A Mol. Integr. Physiol. 215, 45-54 (2018).

97. Yildiz, H. Y., Radosavljevic, V., Parisi, G. \& Cvetkovikj, A. Insight into risks in aquatic animal health in aquaponics. In Aquaponics Food Production Systems. 435-452 (Springer, Cham, 2019).

98. Lekang, O.I. Aquaculture Engineering (John Wiley \& Sons, UK, 2013).

99. Hammer, T., Sanders, J.G. \& Fierer, N. Not all animals need a microbiome. FEMS Microbiol. Lett. 366; fnz117 (2019).

100. Nikouli, E. et al. Gut Microbiota of Five Sympatrically Farmed Marine Fish Species in the Aegean Sea. Microb. Ecol. 1; 10.1007/s00248-020-01580-z (2020).

101. Mente, E., Nikouli, E., Antonopoulou, E., Martin, S.A.M. \& Kormas, A.K. Core vs. feed-associated and postprandial bacterial communities of the rainbow trout (Oncorhynchus mykiss) midgut and feaces. Biol. Open 7; 10.1242/bio.034397 (2018).

102. Palm, H. W., Knaus, U., Appelbaum, S., Strauch, S. M. \& Kotzen, B. Coupled Aquaponics systems. In Aquaponics Food Production Systems 163-199 (Springer, 2019).

103. Castillo-Castellanos, D. et al. Implementation of an experimental nutrient film technique-type aquaponic system. Aquac. Int. 24, 637-646 (2016). 
Figure 1

Aquaponic system diagram

Schematic diagram of the constructed aquaponics system. Arrows indicate the water flow.

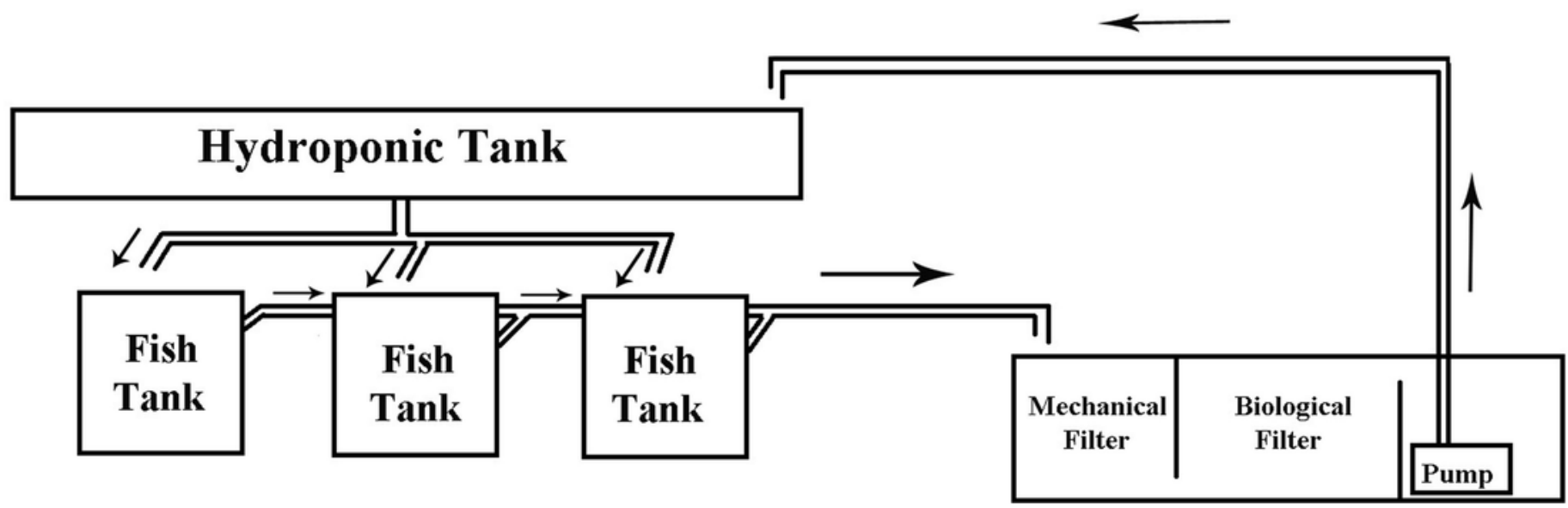


Figure 2

Feeding frequencies

Each of the three aquaponic system $(\mathrm{A}-\mathrm{C})$ was represented by all three feeding frequencies.

The letters FF2, FF4, FF8 refer to feeding frequencies of 2, 4 and 8 days/day respectively. 

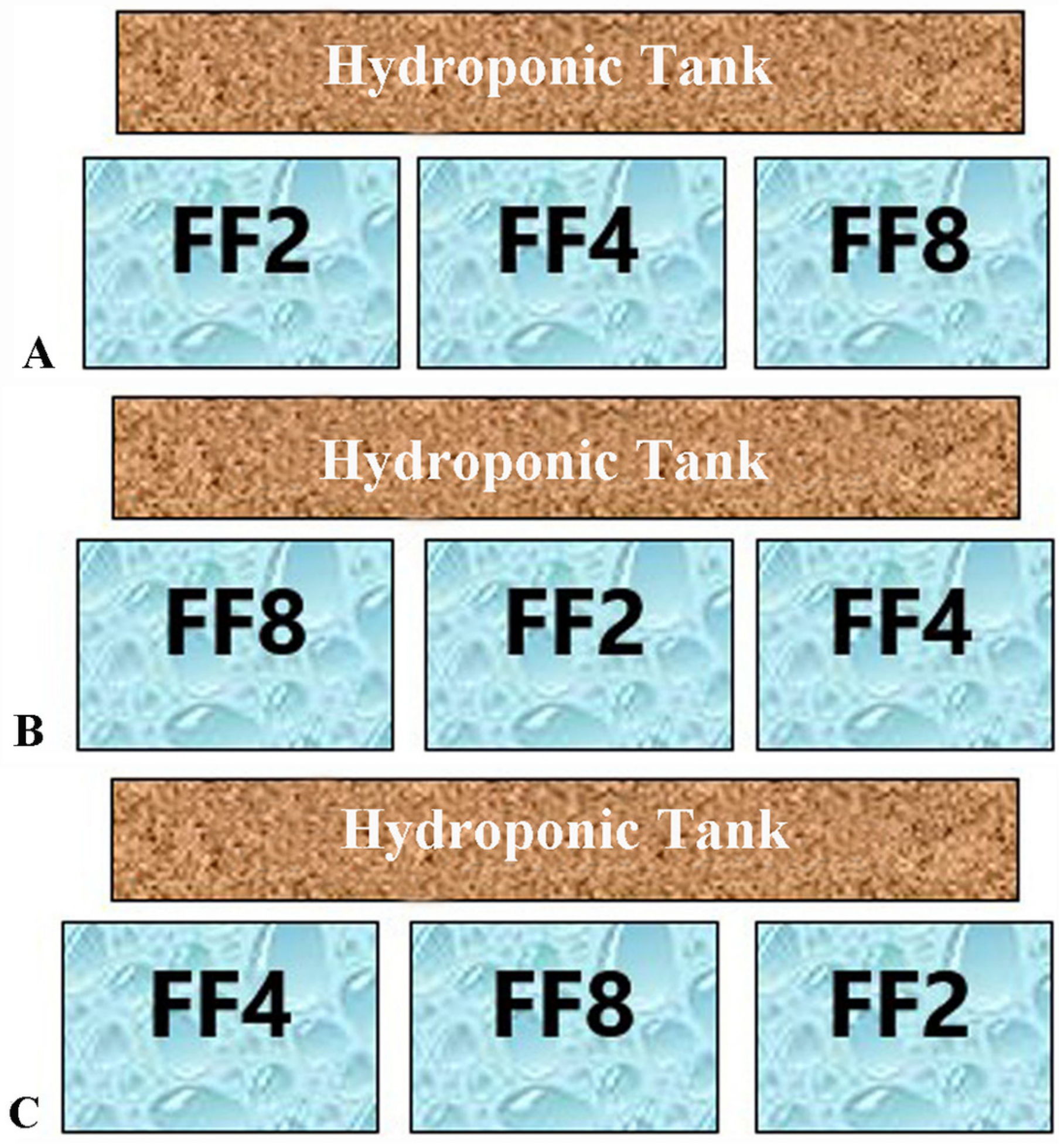


\section{Figure 3}

Liver and midgut histopathology

A) FF2 group. Normal histological structure of liver. B) FF4 group. Mild accumulation of lipid droplets in liver cells (arrows). Some of the nuclei of the liver cells are pushed by the lipid droplets to the edge of the cells (arrowheads). C) FF8 group. Mild accumulation of lipid droplets in liver cells (arrows). Normal midgut structure. D) FF4 group. Normal midgut villi structure, with normal enterocytes. E) FF2 group. Normal midgut villi structure, with normal enterocytes. F) FF8 group. Normal midgut villi structure, with normal enterocytes. 

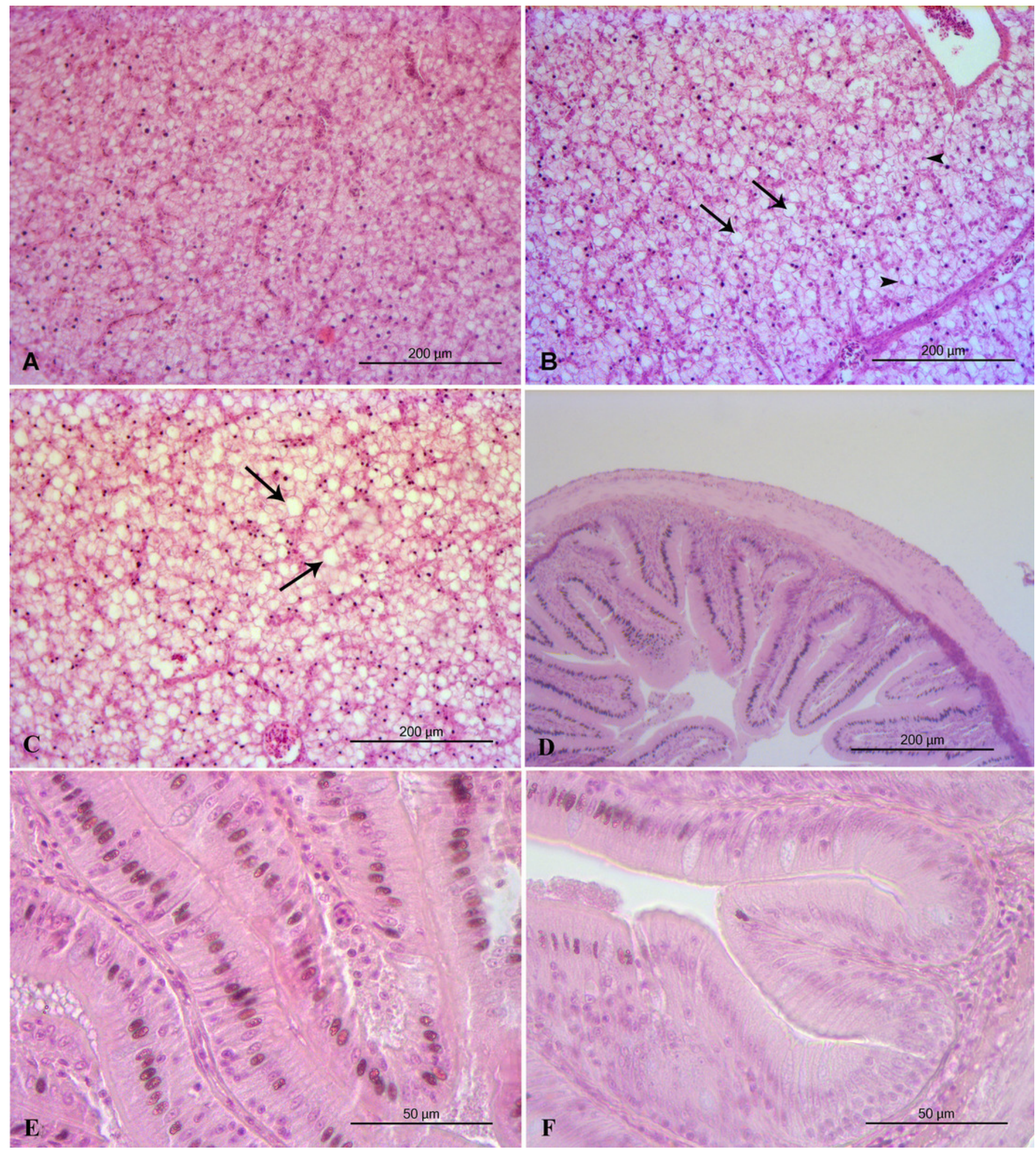


\section{Figure 4}

Kidney and gills histopathology

A) FF2 group. Normal kidney structure. B) FF4 group. Normal kidney structure. C) FF4 group. Normal kidney structure. D) FF2 group. Epithelium detachment at the secondary lamellae (arrowheads). E) FF4 group. Normal gills structure. F) FF8 group. Hyperplasia of primary lamella. Secondary lamellae (arrowheads) appeared trapped in the primary lamella. 

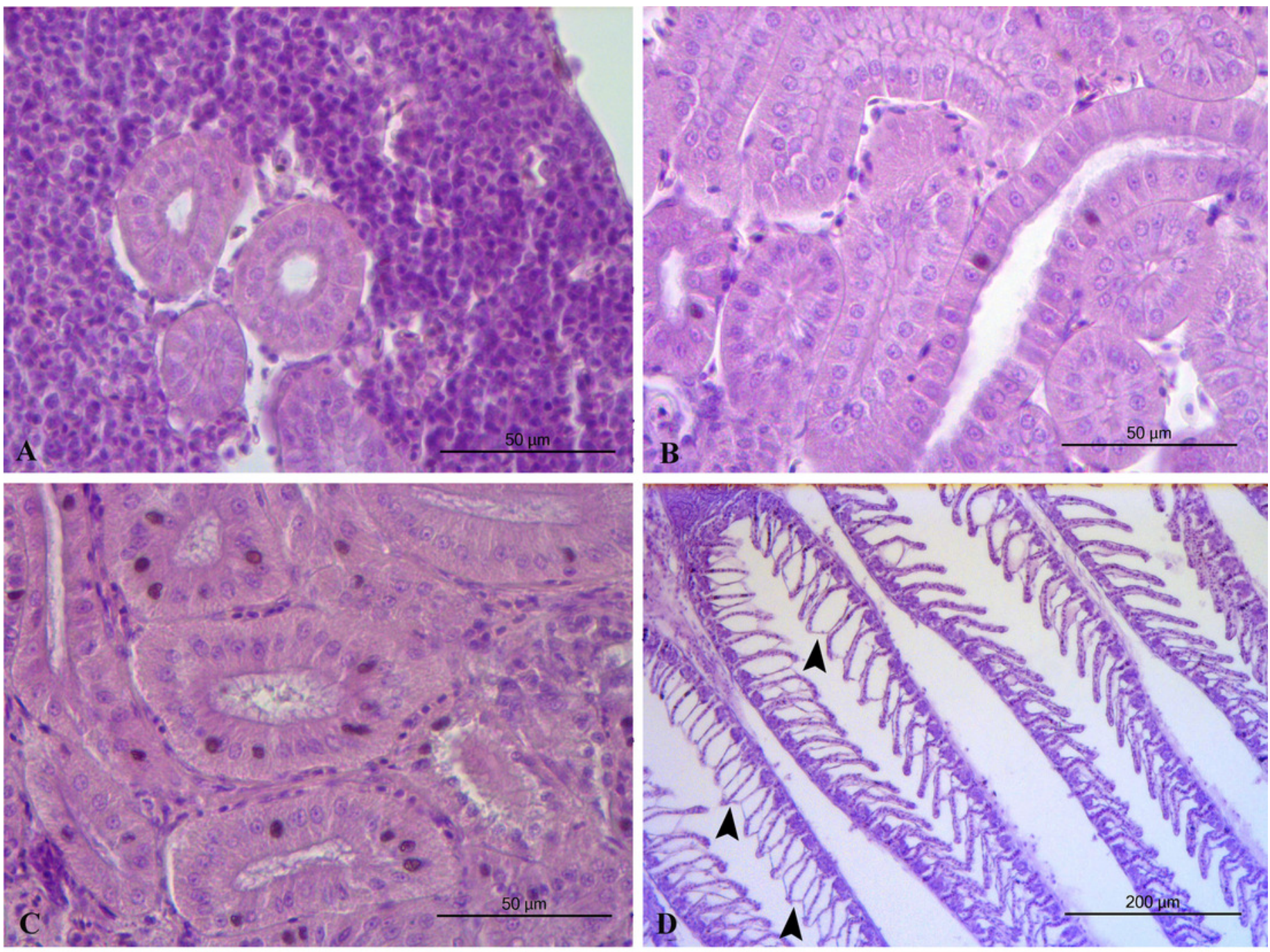

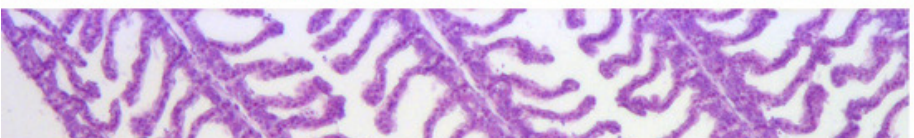

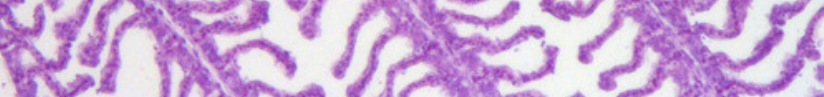

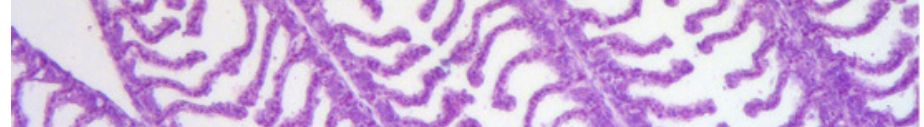
Tी

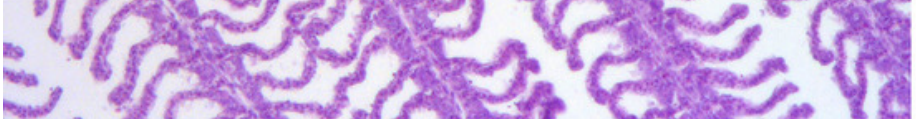
$\because$,

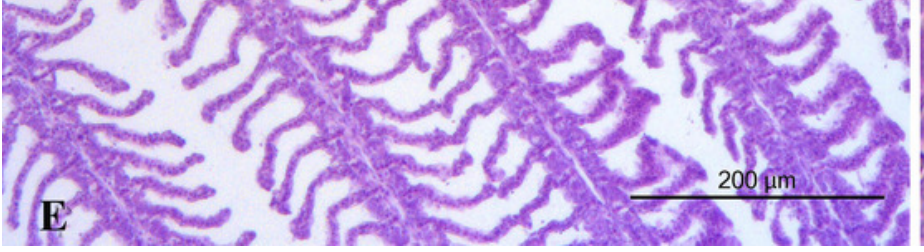

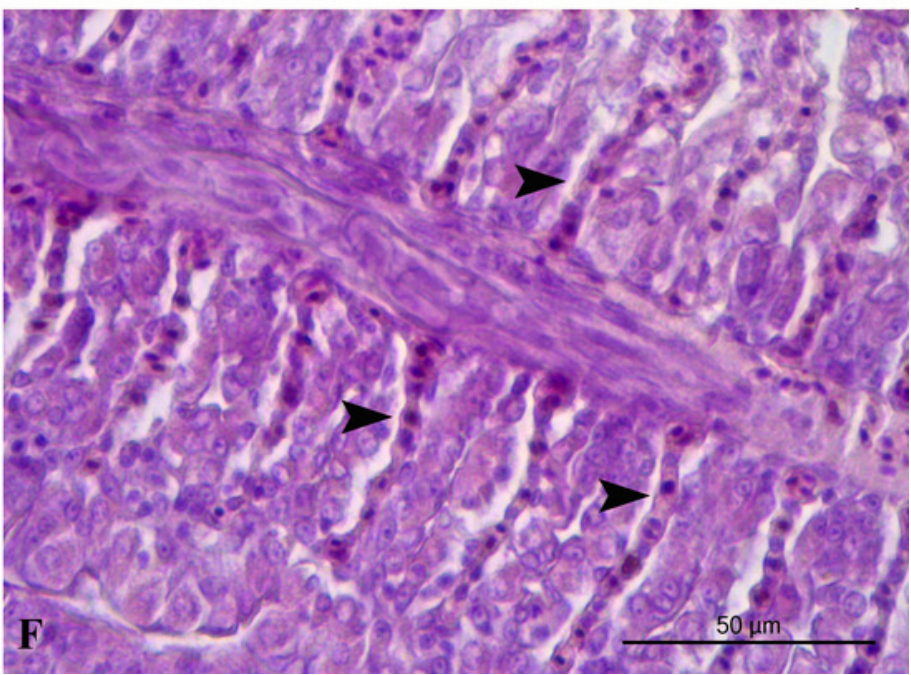




\section{Table $\mathbf{1}$ (on next page)}

Water physicochemical parameters in the fish tanks over 45 days

Water physicochemical parameters in the fish tanks over 45 days 
Table 1: Water physicochemical parameters in the fish tanks over 45 days

\begin{tabular}{llll}
\hline & $\mathrm{FF} 2$ & $\mathrm{FF} 4$ & $\mathrm{FF}$ \\
\hline $\mathrm{pH}$ & $6.75 \pm 0.07^{\mathrm{a}}$ & $6.76 \pm 0.70^{\mathrm{a}}$ & $6.77 \pm 0.07^{\mathrm{a}}$ \\
$\mathrm{EC}(\mathrm{mS} / \mathrm{cm})$ & $1.28 \pm 0.01^{\mathrm{a}}$ & $1.28 \pm 0.011^{\mathrm{a}}$ & $1.28 \pm 0.11^{\mathrm{a}}$ \\
Salinity $(\mathrm{ppt})$ & $0.64 \pm 0.01^{\mathrm{a}}$ & $0.64 \pm 0.01^{\mathrm{a}}$ & $0.64 \pm 0.01^{\mathrm{a}}$ \\
$\mathrm{O}_{2}$ (mg/L) & $8.59 \pm 0.05^{\mathrm{a}}$ & $8.50 \pm 0.06^{\mathrm{a}}$ & $8.52 \pm 0.06^{\mathrm{a}}$ \\
\hline
\end{tabular}

1 Data are expressed as mean \pm S.E.M. $\left(n=45\right.$ for $\mathrm{pH}$ and $\mathrm{n}=15$ for $\mathrm{EC}$, salinity, $\left.\mathrm{O}_{2}\right)$. Means in a row followed

2 by the same superscript are not significantly different $(p>0.05)$. EC: electrical conductivity. 


\section{Table 2 (on next page)}

Water quality of the three aquaponic systems over 45 days.

Water quality of the three aquaponic systems over 45 days. 
1

Table 2. Water quality of the three aquaponic systems over 45 days.

System 1

\begin{tabular}{lllllll}
\hline$(\mathrm{mg} / \mathrm{L})$ & GBin & GBout & GBin & GBout & GBin & GBout \\
\hline $\mathrm{NH}_{4}{ }^{+}$ & $0.17 \pm 0.03^{\mathrm{a}}$ & $0.09 \pm 0.02^{\mathrm{A}}$ & $0.13 \pm 0.02^{\mathrm{a}}$ & $0.07 \pm 0.02^{\mathrm{A}}$ & $0.15 \pm 0.04^{\mathrm{a}}$ & $0.08 \pm 0.02^{\mathrm{A}}$ \\
$\mathrm{NH}_{3}$ & $0.16 \pm 0.02^{\mathrm{a}}$ & $0.08 \pm 0.02^{\mathrm{A}}$ & $0.12 \pm 0.02^{\mathrm{a}}$ & $0.06 \pm 0.02^{\mathrm{A}}$ & $0.14 \pm 0.04^{\mathrm{a}}$ & $0.07 \pm 0.02^{\mathrm{A}}$ \\
$\mathrm{NO}_{3}{ }^{-}$ & $95.30 \pm 16.88^{\mathrm{a}}$ & $81.44 \pm 15.02^{\mathrm{A}}$ & $96.30 \pm 23.51^{\mathrm{a}}$ & $86.16 \pm 13.11^{\mathrm{A}}$ & $89.06 \pm 14.93^{\mathrm{a}}$ & $72.03 \pm 11.31^{\mathrm{A}}$ \\
$\mathrm{PO}_{4}{ }^{3-}$ & $37.270 \pm 4.65^{\mathrm{a}}$ & $39.62 \pm 3.61^{\mathrm{A}}$ & $40.40 \pm 4.30^{\mathrm{a}}$ & $44.52 \pm 3.48^{\mathrm{A}}$ & $37.44 \pm 4.33^{\mathrm{a}}$ & $38.78 \pm 3.98^{\mathrm{A}}$
\end{tabular}

2 Data are expressed as mean \pm S.E.M. $(n=7)$. Means in a row per water inlet point (GBin) or exit point

3 (GBout) of the hydroponic cultivation tank followed by the same superscript a or $A$ are not significantly

4 different $(p>0.05)$.

5 


\section{Table 3 (on next page)}

Functional characteristics of the filter in the aquaponic systems over 45 days.

Functional characteristics of the filter in the aquaponic systems over 45 days. 


\begin{tabular}{|c|c|c|c|c|}
\hline Filter indexes & System 1 & System 2 & System 3 & $d$ as mea \\
\hline $\mathrm{HLR}(\mathrm{cm} / \mathrm{d})$ & $0.95 \pm 0.04^{a}$ & $0.96 \pm 0.05^{a}$ & $0.96 \pm 0.01^{a}$ & $(n=9)$ \\
\hline HRT (min) & $7.47 \pm 0.03^{a}$ & $7.46 \pm 0.01^{\mathrm{a}}$ & $7.49 \pm 0.01^{a}$ & $\begin{array}{l}\text { Means in } \\
\text { a row }\end{array}$ \\
\hline$Q\left(m^{3} / d\right)$ & $7.26 \pm 0.03^{a}$ & $7.34 \pm 0.03^{a}$ & $7.29 \pm 0.02^{\mathrm{a}}$ & $\begin{array}{l}\text { followed } \\
\text { by the }\end{array}$ \\
\hline$r$ & $0.90 \pm .0 .01^{a}$ & $0.90 \pm 0.01^{a}$ & $0.90 \pm 0.01^{a}$ & same \\
\hline $\mathrm{P}_{\text {TAN }}(\mathrm{mg} / \mathrm{L})$ & $6.69 \pm 0.66^{a}$ & $6.18 \pm 0.47^{a}$ & $6.71 \pm 0.75^{\mathrm{a}}$ & $\begin{array}{l}\text { superscri } \\
\text { pt are not }\end{array}$ \\
\hline $\mathrm{SSA}\left(\mathrm{m}^{2} / \mathrm{m}^{3}\right)$ & $362.9 \pm 36.19^{a}$ & $334.9 \pm 25.29^{a}$ & $363.82 \pm 40.56^{a}$ & $\begin{array}{l}\text { significant } \\
\text { ly different }\end{array}$ \\
\hline $\mathrm{V}_{\text {filter media }}(\mathrm{L})$ & $12.73 \pm 1.26^{a}$ & $11.75 \pm 0.88^{a}$ & $12.77 \pm 1.42^{\mathrm{a}}$ & (ANOVA, \\
\hline$V_{\text {filter }}(\mathrm{L})$ & 184.2 & 184.6 & 184.9 & $\begin{array}{l}p>0.05) . \\
\text { HIR. }\end{array}$ \\
\hline
\end{tabular}
Loading Ratio, HRT: Hydraulic Retention Time, Q: Flow Rate, r: Volume of recycled water/volume of the system, $\mathrm{P}_{\text {TAN }}$ : Production rate of ammonia nitrogen, SSA: Surface area of filter media/volume of the filter media, $\mathrm{V}_{\text {filter media: }}$ Volume of filter media, $\mathrm{V}_{\text {filter }}$ : filter volume 


\section{Table 4 (on next page)}

Growth performances of sea bass fed at three different feeding frequency over 45 days.

Growth performances of sea bass fed at three different feeding frequency over 45 days. 
Table 4. Growth performances of sea bass fed at three different feeding frequency over 45 days.

\begin{tabular}{llll}
\hline & $F F 2$ & $F F 4$ & FF8 \\
\hline Survival $(\%)$ & $77.2^{1} \pm 14.99$ & $96.50 \pm 1.75$ & $96.50 \pm 1.75$ \\
Initial weight $\left(\mathrm{W}_{\mathrm{i}}, \mathrm{g}\right)$ & $6.80 \pm 0.18^{\mathrm{a}}$ & $6.78 \pm 0.17^{\mathrm{a}}$ & $6.81 \pm 0.15^{\mathrm{a}}$ \\
Final weight $\left(\mathrm{W}_{\text {fin }}, \mathrm{g}\right)$ & $17.44 \pm 0.59^{\mathrm{b}}$ & $20.29 \pm 0.77^{\mathrm{a}}$ & $21.11 \pm 0.65^{\mathrm{a}}$ \\
Weight gain $(\mathrm{WG}, \mathrm{g})$ & $10.66 \pm 0.40^{\mathrm{b}}$ & $13.14 \pm 0.59^{\mathrm{a}}$ & $13.85 \pm 0.50^{\mathrm{a}}$ \\
Specific growth rate (SGR, \%/day) & $2.11 \pm 0.05^{\mathrm{b}}$ & $2.23 \pm 0.03^{\mathrm{a}}$ & $2.36 \pm 0.02^{\mathrm{a}}$ \\
Food Conversion ratio (FCR) & $1.6 \pm 0.51^{\mathrm{a}}$ & $1.4 \pm 0.42^{\mathrm{a}}$ & $1.3 \pm 0.37^{\mathrm{a}}$ \\
Voluntary Feed Intake (VFI) & $2.72 \pm 0.06^{\mathrm{a}}$ & $2.73 \pm 0.04^{\mathrm{a}}$ & $2.64 \pm 0.01^{\mathrm{a}}$ \\
Initial length $\left(\mathrm{L}_{\mathrm{i}}, \mathrm{cm}\right)$ & $8.54 \pm 0.09^{\mathrm{a}}$ & $8.68 \pm 0.08^{\mathrm{a}}$ & $8.64 \pm 0.08^{\mathrm{a}}$ \\
Final length $\left(\mathrm{L}_{\text {fin }}, \mathrm{cm}\right)$ & $11.66 \pm 0.13^{\mathrm{b}}$ & $12.02 \pm 0.13^{\mathrm{ab}}$ & $12.16 \pm 0.11^{\mathrm{a}}$ \\
\hline
\end{tabular}

${ }^{1}$ On the day 16th an unexplained fish mortality was observed (10 fish) for the FF2 group. This was probably due to anaesthesia fish handling. Consequently, it had no relation with the feeding procedures.

Data are expressed as means \pm S.E.M. Means in a row followed by the same superscript are not significantly different $(p>0.05)$.

1 


\section{Table 5 (on next page)}

Severity score (0-4) for the observed histopathological alterations

Severity score (0-4) for the observed histopathological alterations 
1 Table 5. Severity score (0-4) for the observed histopathological alterations

\begin{tabular}{llllll} 
& Feeding frequency per day & Liver & Midgut & Kidney & Gills \\
\cline { 2 - 6 } 2 & FF2 & 2 & 0 & 0 & 1 \\
& FF4 & 2 & 0 & 0 & 1 \\
3 & FF8 & 2 & 0 & 0 & 2 \\
\cline { 2 - 5 }
\end{tabular}




\section{Table 6(on next page)}

Bray-Curtis similarity PERMANOVA results for between days (D) and times of feeding (td). $F$ values upper half, $p$ values lower half.

Bray-Curtis similarity PERMANOVA results for between days (D) and times of feeding (td). F values upper half, $p$ values lower half. 
1 Table 6. Bray-Curtis similarity PERMANOVA results for between days (D) and feeding frequency (FF). F

2 values upper half, $p$ values lower half.

\begin{tabular}{cccccccc}
\hline & D0 & D15-FF2 & D45-FF2 & D15-FF4 & D45-FF4 & D15-FF8 & D45-FF8 \\
\hline D0 & - & 1.214 & 1.325 & 1.169 & 0.966 & 1.237 & 1.221 \\
D15-FF2 & 0.297 & - & 1.590 & 1.051 & 1.162 & 1.579 & 1.330 \\
D45-FF2 & 0.101 & 0.103 & - & 1.470 & 1.567 & 1.179 & 1.525 \\
D15-FF4 & 0.101 & 0.295 & 0.099 & - & 1.299 & 1.550 & 1.155 \\
D45-FF4 & 0.499 & 0.298 & 0.099 & 0.104 & - & 1.403 & 1.038 \\
D15-FF8 & 0.104 & 0.105 & 0.298 & 0.104 & 0.097 & - & 1.141 \\
D45-FF8 & 0.098 & 0.103 & 0.099 & 0.204 & 0.498 & 0.398 & -
\end{tabular}

3 D0: Day 0; Dx-FFy: Sampling at the day $x$ while feeding frequency was y times per day. i.e. D15-FF2:

4 sampling at day 15 while feeding frequency was 2 times per day.

5

6

7

8

9

10 
Table 7 (on next page)

Plant growth performance

Plant growth performance 
Table 7. Plant growth performance

\begin{tabular}{lccc}
\hline & System 1 & System 2 & System 3 \\
\hline Survival $(\%)$ & 100 & 100 & 100 \\
Stem height $(\mathrm{cm})$ & $7.73 \pm 0.38^{\mathrm{b}}$ & $7.64 \pm 0.35^{\mathrm{b}}$ & $9.63 \pm 0.44^{\mathrm{a}}$ \\
Total fresh weight of leaves $(\mathrm{gr})$ & $428.703 \pm 47.58^{\mathrm{a}}$ & $375.23 \pm 29.03^{\mathrm{a}}$ & $457.45 \pm 21.39^{\mathrm{a}}$ \\
Number of leaves per plant & $43.88 \pm 2.73^{\mathrm{a}}$ & $34 \pm 0.87^{\mathrm{b}}$ & $43.63 \pm 1.68^{\mathrm{a}}$ \\
Leaf fresh weight $(\mathrm{gr})$ & $9.60 \pm 0.66^{\mathrm{a}}$ & $10.98 \pm 0.68^{\mathrm{a}}$ & $10.52 \pm 0.41^{\mathrm{a}}$ \\
Total fresh aerial biomass $(\mathrm{gr})$ & $463.04 \pm 51.03^{\mathrm{a}}$ & $402.52 \pm 31.66^{\mathrm{a}}$ & $496.06 \pm 23.96^{\mathrm{a}}$ \\
Total dry aerial biomass $(\mathrm{gr})$ & $23.20 \pm 2.42^{\mathrm{a}}$ & $17.23 \pm 1.50^{\mathrm{a}}$ & $21.47 \pm 1.57^{\mathrm{a}}$ \\
Root dry biomass $(\mathrm{gr})$ & $3.41 \pm 0.54^{\mathrm{ab}}$ & $2.32 \pm 031^{\mathrm{b}}$ & $4.64 \pm 0.90^{\mathrm{a}}$ \\
Total produced biomass $\left(\mathrm{kg} / \mathrm{m}^{2}\right)$ & 3.70 & 3.22 & 3.97 \\
\hline
\end{tabular}

1 Data are expressed as means \pm S.E.M $(n=8)$. Means in a row followed by the same superscript are not 2 significantly different $(p>0.05)$. 